\title{
Composition, Quality and Health Aspects of the Dromedary (Camelus dromedarius) and Bactrian (Camelus bacterianus) Camel Meats: A Review
}

\author{
Isam T. Kadim ${ }^{1 *}$, Osman Mahgoub', Waleed Al-Marzooqi', \\ Samera K. Khalaf' ${ }^{1}$, and Gulzhan Raiymbek ${ }^{2}$ \\ ${ }^{1}$ Department of Animal and Veterinary Sciences, College of Agricultural and Marine Sciences, \\ Sultan Qaboos University, PO Box 34, Muscat, Sultanate of Oman \\ ${ }^{2}$ Al-Farabi Kazkh National University, Almaty, Kazakhstan

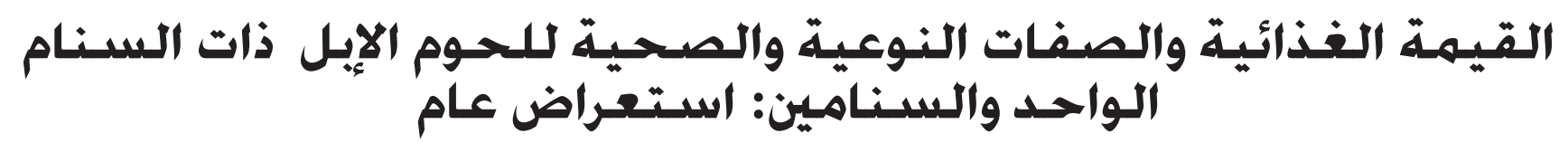

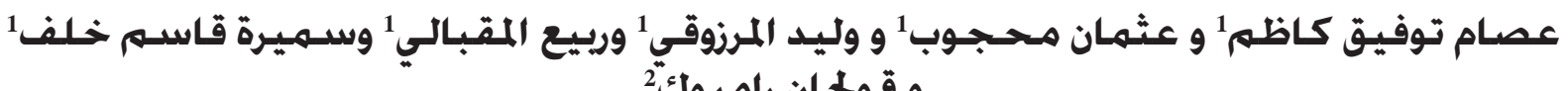

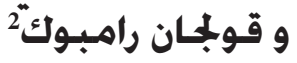

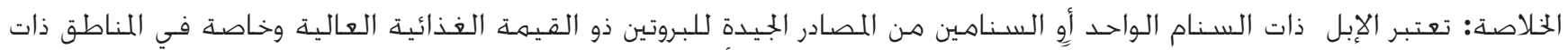

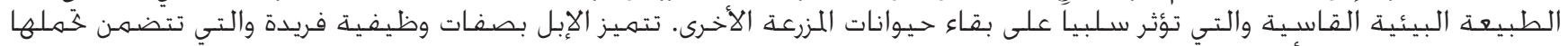

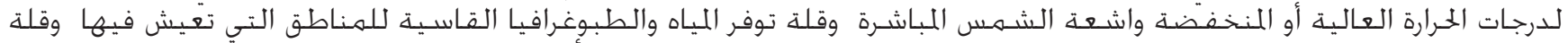

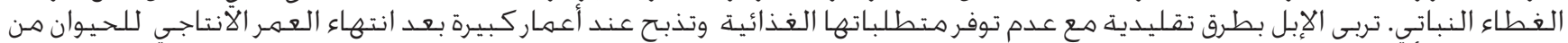

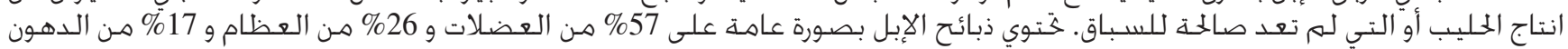

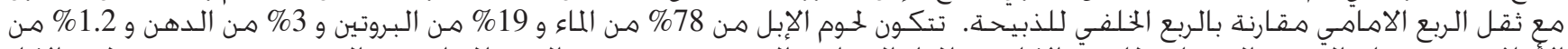

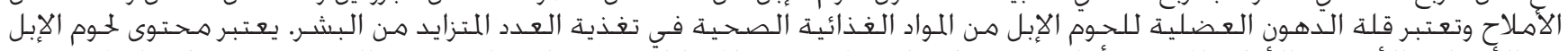

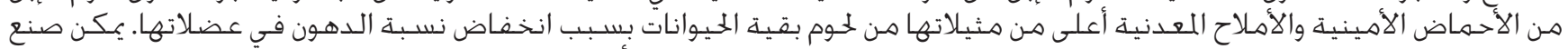

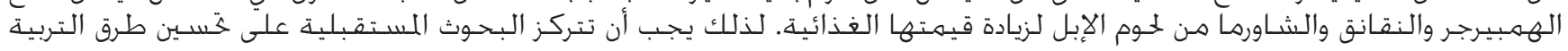

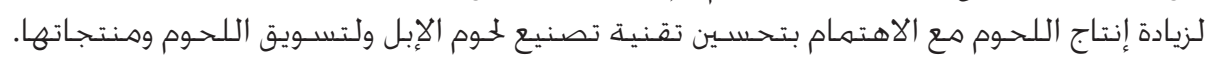 \\ كلمات مفتاحية: ابل ، الصفـات النوعية ، القيمة الغذائية ، التركيب الكيميائي ، تصنيع اللحـوم.
}

\begin{abstract}
The dromedary and bactrian camels are good sources of high quality protein especially in areas where the climate adversely affects the survival of other livestock. The camel has unique physiological characteristics, including a great tolerance to high and low temperatures, solar radiation, water scarcity, rough topography and poor vegetation. Camels are mostly produced under traditional systems on poor levels of nutrition and are mostly slaughtered at old ages after completing a career in work, racing or milk production. In general, camel carcasses contain about $57 \%$ muscle, $26 \%$ bone and $17 \%$ fat with fore-quarters (cranial to rib 13) significantly heavier than the hind halves. Camel lean meat contains about $78 \%$ water, $19 \%$ protein, $3 \%$ fat, and $1.2 \%$ ash with a small amount of intramuscular fat, which renders it a healthy food for growing human populations. The amino acid and mineral contents of camel meat are often higher than other meat animals, probably due to lower intramuscular fat levels. Camel meat has been processed into burgers, patties, sausages and shawarma to add value. Future research efforts need to focus on exploiting the potential of the camel as a source of meat through multidisciplinary research into efficient production systems and improved meat technology and marketing.
\end{abstract}

Keywords: Camel, meat quality, nutritive value, meat composition, meat processing.

\section{Introduction}

The family Camelidae include two subfamilies: Camelinae (Old World Camelids) and Laminae (New World Camelids). The subfamily Camelidae includes two species: Camelus dromedarius and Camelus bacterianus. The dromedary or the one-humped camel (Camelus dromedarius) is mostly distributed in the hot arid areas of the Middle East, Asia and Africa, whereas the bactrian two-humped camel (Camelus 
bacterianus) is found in central Asia, Kazakhstan, Russia and China (Dorman, 1986). The New World camelids consist of the following species: the guanaco (Lama guanacoe) and the vicuna (Vicugna vicugna), which are wild and the llama (Lama glama) and the alpaca (Lama pacos), which are domesticated and mainly found in South America (Murray, 1989). The camel was domesticated by secondary nomads around 5000 years ago in South Arabia primarily for transport and labour (Wilson, 1998). The dromedary is more abundant than the bactrian camel representing almost $90 \%$ of the genus Camelus. Phylogenetic analysis (micro-satellite loci) showed that camel breeds can be classified according to countries of origin (Mburu et al., 2003).

The camel is an important domestic animal in various countries for producing valuable food and for its adaptation to extremely harsh environments (Kadim et al., 2008). It can survive on sandy terrain with poor vegetation and may chiefly consume feeds unutilized by other domestic species (Tandon et al., 1988). Therefore, the role of the camel as a meat producer is becoming more important due to the versatile role it plays rather than as a symbol of social prestige, which was the major role it used to play, and which has since greatly diminished (Dawood and Alkanhal, 1995). Camel meat is described as tough, coarse, watery and sweetish in taste compared to meats from other animals. This may be partly attributed to the fact that camel meat is usually a by-product of primitive traditional systems of production where it is mainly obtained from old males and females that have become less effective in their primary roles of providing transportation, milk, or as breeding females (Kadim et al., 2008). However, evidence suggests that the quality characteristics of camel meat are not much different from beef if animals are slaughtered at comparable ages (Khatami, 1970; Knoess, 1977; Elgasim et al., 1987; Tandon et al., 1988; Kadim et al., 2011).

Although the marketing systems for camel meat are not well organised, there is evidence of a high demand for camel meat (Kadim et al., 2008). Camel meat could be a good source to meet the growing needs for meat in developing countries, especially for low income population groups (Kadim et al., 2008). Generally, camel meat is a significant source of animal protein and preferred over other meat animal species due both to the belief in it medicinal benefits and to its availability at affordable prices. This review outlines the nutritional and health value, quality characteristics and the availability of muscle bioactive compounds in dromedary and bactrian camel meats. A comparison of the nutritional properties of dromedary and bactrian camel meats with other species is also highlighted.

\section{Chemical Composition of Camel Meat}

Camel meat composition varies according to breed, age, sex, condition and location on the carcass. However, the composition of camel meat is generally similar to meat from other species where an inverse relationship existed between the moisture and protein and fat content of the meat (Table 1). Composition is an important indicator of meat functionality. For instance, moisture content plays an important role in keeping and eating qualities of camel meat (Kadim et al., 2008) whereas protein and fat contents dictate the manufacturing quality of meat.

Table 1 shows that moisture content varies widely in camel meat (67.8 to $78.9 \%$ ). Different muscles within the same camel carcass appear to have similar moisture contents (Babiker and Yousif, 1990; Gheisari et al., 2009; Kadim et al., 2013) as well as for the bactrian (Raiymbek et al., 2012a). However, the range of moisture content of Biceps femoris (74.3-78.5\%) and Triceps brachii (77.7$78.4 \%)$ muscles was higher than those from Longissimus dorsi muscle (72.1-73.8\%) due to the higher fat content in the Longissimus thoracis muscle (Kadim et al., 2013; Raiymbek et al., 2012a). According to Kadim et al. (2006), the moisture content of dromedary camel meat decreases with the increases in the animal age. The differences between the maximum and minimum moisture contentsof camel Longissimus thoracis were 3.2, 6.4 and $12.3 \%$ for $1-3,3-5$ and 6-8 years age groups, respectively (Kadim et al., 2006). This indicates that the variation in moisture content within the samples is greater in older animals. Gheisari et al. (2009) found no differences in moisture content between camel meat and meat from other species at a similar age and sex.

The protein content of camel meat is in the range of 17.0 to $23.7 \%$ (Table 1). There are slight differences between various muscles and different age groups (ElFaer et al. 1991; Kadim et al., 2006, 2012; Raiymbek et al., 2012a). Meat from young camels has similar protein content to those found in young cattle, lamb and goat meats (Elgasim and Alkanhal, 1992; Kadim et al., 2009b). The protein contents of six skeletal muscles (Semitendinosus, Infraspinatus, Semimembranosus, Biceps femoris, Triceps brachii and Longissimus thoracis) in dromedary and bactrian camels were studied by Kadim et al. (2013) and Raiymbek et al. (2012a). The highest protein content was found in the Semitendinosus muscle in bactrian, while the Semimembranosus contained the highest protein content in dromedary camel (Kadim et al., 2013; Raiymek et al., 2012a). Total collagen content is higher in camel Longissimus thoracis muscle than in Semitendinosus or Triceps brachii muscles, possibly due to morphological requirement for stabilizing the hump attached to the Longissimus thoracis (Babiker and Yousif, 1990).

The fat content of camel meat ranged from 1.1 to $10.6 \%$ (Table 1). Differences in the fat content in various camel muscles were reported (El-Faer et al., 1991; Elgasim and Alkanhal, 1992; Kadim et al., 2006, 2008, 2009a,b; Gheisari et al., 2009). An animal's age has a great effect on the fat content, with camel meat from older animals' containing higher fat compared with meat from younger animals (Kadim et al., 2006).

The ash content in the dromedary and bactrian camel meats has been reported in the range of 0.75 to 
Table 1. Chemical composition (\%) of dromedary and bactrian camel muscles.

\begin{tabular}{|c|c|c|c|c|c|}
\hline Muscle Type & Moisture & Protein & Fat & Ash & \\
\hline \multicolumn{6}{|l|}{ Dromedary camel } \\
\hline Longissimus thoracis & 73.8 & 19.0 & 6.2 & 0.85 & \multirow{6}{*}{ Kadim et al. (2013) } \\
\hline Infraspintus & 73.2 & 18.2 & 5.3 & 0.96 & \\
\hline Triceps brachii & 77.7 & 17.1 & 1.9 & 1.00 & \\
\hline Semitendinosus & 75.4 & 18.5 & 3.1 & 0.91 & \\
\hline Semimembranosus & 63.0 & 22.1 & 2.5 & 0.93 & \\
\hline Biceps femoris & 74.3 & 20.8 & 2.5 & 1.00 & \\
\hline Longissimus thoracis & 65.7 & 19.5 & 2.1 & 1.20 & \multirow{2}{*}{$\begin{array}{l}\text { Kadim et al. (2011) } \\
\text { Al-Bachir \& Zeinou (2009) }\end{array}$} \\
\hline Longissimus thoracis & 73.8 & 23.7 & 3.6 & - & \\
\hline Biceps femoris & 73.0 & 22.8 & 1.1 & 0.75 & \multirow{6}{*}{ Gheisari et al., (2009) } \\
\hline Triceps brachii & 72.0 & 21.2 & 1.4 & 0.81 & \\
\hline Longissimus dorsi & 68.3 & 21.5 & 1.6 & 0.69 & \\
\hline Biceps femoris & 71.4 & 22.2 & 1.6 & 0.98 & \\
\hline Triceps brachii & 70.5 & 20.3 & 2.4 & 1.06 & \\
\hline Longissimus dorsi & 67.8 & 20.5 & 2.5 & 0.95 & \\
\hline Longissimus thoracis & 74.8 & 21.1 & 2.8 & 1.34 & \multirow{5}{*}{$\begin{array}{l}\text { Kadim et al. (2009a) } \\
\text { Kadim et al. (2006) } \\
\text { Babiker and \&Yousif (1990) }\end{array}$} \\
\hline Longissimus thoracis & 71.7 & 22.7 & 4.4 & 1.10 & \\
\hline Longissimus dorsi & 75.9 & 21.6 & 1.4 & 1.05 & \\
\hline Semitendinosus & 75.8 & 21.4 & 1.4 & 1.38 & \\
\hline Triceps brachii & 75.2 & 22.1 & 1.4 & 1.22 & \\
\hline \multicolumn{6}{|l|}{ Bactrian camel } \\
\hline Longissimus thoracis & 72,1 & 17.0 & 10.0 & 0.9 & \multirow{6}{*}{ Raiymbek et al. (2012a) } \\
\hline Infraspintus & 78.5 & 18.0 & 2.5 & 1.0 & \\
\hline Triceps brachii & 78.4 & 17.5 & 3.0 & 1.0 & \\
\hline Semitendinosus & 78.0 & 18.8 & 2.2 & 1.0 & \\
\hline Semimembranosus & 79.0 & 18.2 & 2.0 & 1.0 & \\
\hline Biceps femoris & 78.5 & 18.3 & 2.1 & 1.1 & \\
\hline
\end{tabular}

$1.38 \%$ (Table 1). Ash content varies with muscles and between muscles (Babiker and Yousif, 1990; Dawood and Alkanhal, 1995; Gheisari et al., 2009; Kadim et al., 2013; Raiymbek et al., 2012a). Gheisari et al. (2009) found that age had a significant effect on ash content of camel meat, whereas others found no effect of age on ash content (ElFaer et al., 1991; Al-Shabib and Abu-Tarboush, 2004; Shehata, 2005; Kadim et al., 2006, 2008). Camel meat has relatively lower ash content than beef, lamb and goat meat (Elgasim and Alkanhal, 1992; Gheisari et al., 2009; Kadim et al., 2008).

\section{Amino Acid Composition}

According to Dawood and Alkanhal (1995), the essential amino acid content of camel meat is not affected by an animal's age. Camel meat has a comparable essential amino acid contents to beef, lamb and goat meat (Table 2 ). The amount of camel meat required to supply the daily requirements of essential amino acids for adult consumer is similar to that from lamb (based on methionine which has the lowest content in meat) but is less than the amount required from beef.

Table 2 shows that leucine ( 7.08 to $9.51 \%$ of protein) and lysine (8.33 to $9.85 \%$ of protein) are among the highest essential amino acids in camel meat. Essential amino acids contents of camel meat varied slightly among different muscle locations in the carcass. The essential amino acid contents in Longissimus dorsi and Semitendinosus muscles differed by $>2.1 \%$ with the exception of leucine, methionine and tryptophan, which differed by $18.5,25.4$ and $14.6 \%$, respectively (AlShabib and Abu-Tarboush, 2004). Similarly, essential amino acid contents in the Infraspinatus, Longissimus dorsi and Semitendinosus muscles differed by $>4.2 \%$ with the exception of isoleucine, methionine, threnonine, tryptophane and valine which differed between 8 to 42\% (Dawood and Alkanhal, 1995). On the other hand, differences in essential amino acids reported across 
Table 2. Essential amino acid composition in camel meat $(\mathrm{mg} / 100 \mathrm{~g})$.

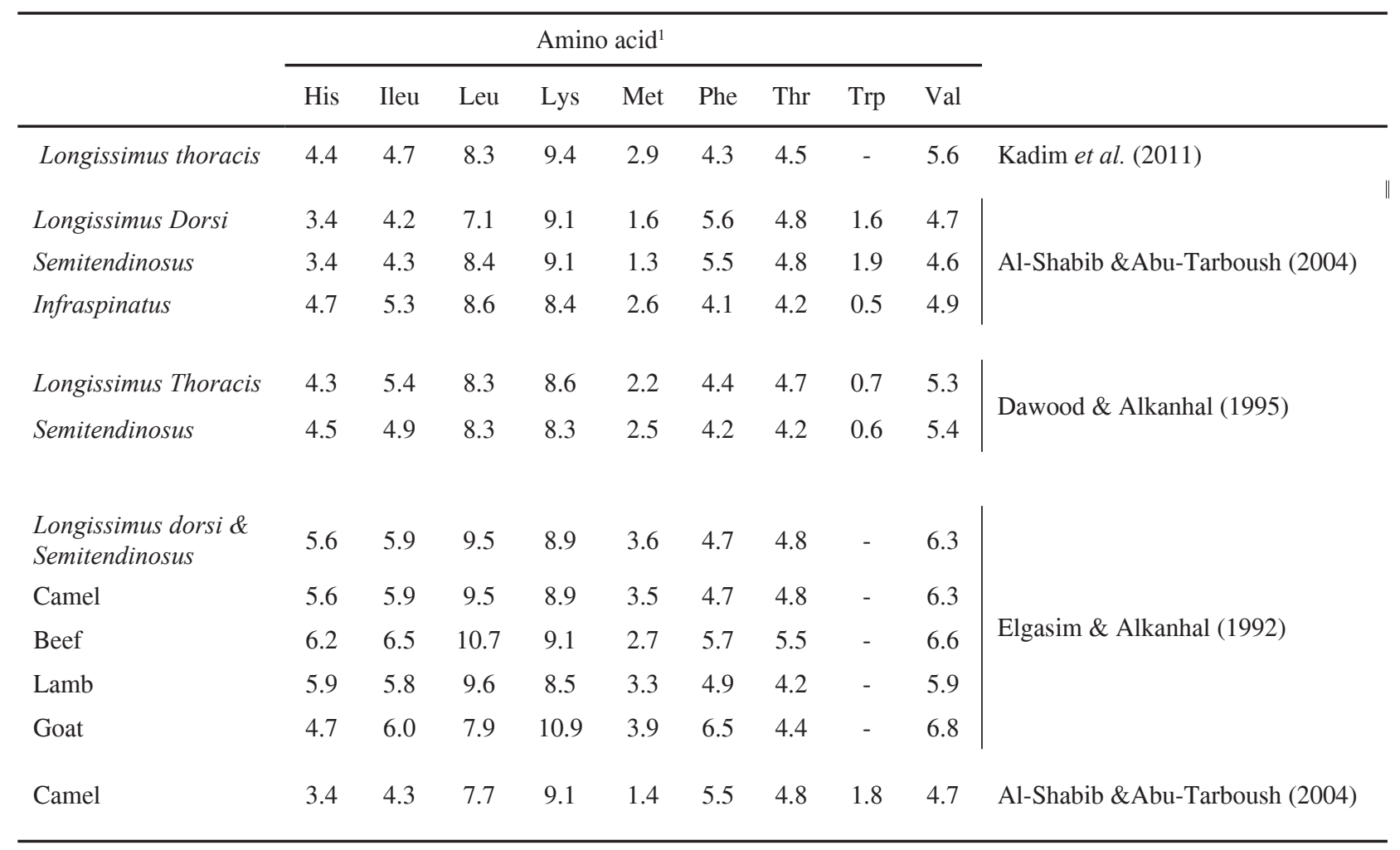

${ }^{1}$ Amino acids: His - Histidine, Ileu - Isoleucine, Leu - Leucine, Lys - Lysine, Met - Methionine, Phe - Phenylalanine, Thr - Threonine, Trp - Tryptophane, Val - Valine

different camel muscles ranged between 0.5 to $9.5 \%$ (Elgasim and Alkanhal, 1992; Dawood and Alkanhal, 1995; Al-Shabib and Abu-Tarboush, 2004). Tryptophan concentration in camel meat was lower than in other meats (Dawood and Alkanhal, 1995). Al-Shabib and AbuTarboush (2004) reported that tryptophan concentration was $1.76 \%$ of the total amino acids, which was higher than the $1.28 \%$ reported for beef (Kadim et al., 2008).

The glutamic and aspartic acids, the major nonessential amino acids in camel meat ranged from 15.95 to $18.60 \%$ and from 9.30 to $10.80 \%$ of protein, respectively (Table 3). Similar to the essential amino acids, nonessential amino acid content also varied slightly between muscles, and larger variations are found between studies. In general, camel meat maybe a better source of nonessential amino acids than beef, lamb, and goat meats (Table 3). Although, Elgasim and Alkanhal (1992) found low alanine levels in camel meat compared to other red meats, Dawood and Alkanhal (1995), Al-Shabib and AbuTarboush (2004) and Kadim et al. (2011) found similar concentration of alanine in camel meats and other red meats.

\section{Fatty Acid Composition}

The fatty acid composition of meat is of great concern to consumers due to its important effects on human health. Reduction of saturated fatty acid intake is very important to prevent obesity, hypercholesterolemia and to decrease the risk of cancer (Chizzolini et al., 1999). On the other hand, diets containing lipids with a high level of monounsaturated fatty acids and polyunsaturated fatty acids have been shown to be effective in lowering serum cholesterol levels (Mensink and Katan, 1989). Rawdah et al. (1994) identified 22 fatty acids in camel meat (Table 5). Major fatty acids in camel meat were also reported by Al-Bachir and Zeinou (2009) and Kadim et al. (2011). Rawdah et al. (1994) reported levels of $18.93 \%$ oleic (C18:1) and $12.07 \%$ linoleic acid (C18:2) in the camel meat. However, about twice the percentage of oleic (C18: 1) and less than half the percentage of linoleic acid (C18: 2) were reported by Al-Bachir and Zeinou (2009) and Kadim et al. (2011). Linoleic acid is derived entirely from the diet (Wood et al., 2008) and such differences are not unexpected from studies from different regions. The major saturated, monounsaturated and polyunsaturated fatty acids in camel meat are (C16:0), (C18:1) and (C18: 2 ), respectively (Table 4). The variation of total saturated fatty acids (51.5-53\%) was small in comparison to monounsaturated (29.9 and 41.4\%) and polyunsaturated (5.6\% and $18.6 \%$ ) fatty acids, which is in agreement with Rawdah et al. (1994) and Kadim et al. (2011).

The fatty acid composition, total saturated, unsaturated, monounsaturated and polyunsaturated fatty acids of Infraspintus, Triceps brachii, Longissimus 
Table 3.Non-essential amino acid composition in camel meat ( $\mathrm{mg} / 100 \mathrm{~g})$.

\begin{tabular}{lcccccccc|c}
\hline & \multicolumn{7}{c}{ Amino acid $^{1}$} & & \\
\cline { 2 - 6 } & Ala & Arg & Asp & Glu & Gly & Pro & Ser & Tyr & \\
\hline Longissimus thoracis & 6.5 & 6.6 & 9.3 & 15.9 & 4.3 & 3.9 & 3.6 & 3.5 & Kadim et al. (2011) \\
Infraspinatus & 6.3 & 7.5 & 9.3 & 17.1 & 6.0 & 5.4 & 3.5 & 3.0 & \\
Longissimus dorsi & 6.2 & 7.1 & 9.3 & 17.3 & 5.9 & 4.9 & 3.8 & 3.4 & Dawood \& Alkanhal (1995) \\
Semitendinosus & 6.3 & 7.5 & 8.6 & 16.4 & 5.9 & 5.9 & 3.6 & 3.3 & \\
Longissimus dorsi & & & & & & & & & \\
and Semitendinosus & 3.9 & 7.1 & 10.8 & 18.6 & 6.1 & 3.9 & 3.2 & 3.8 & \\
Camel & 3.9 & 7.1 & 10.8 & 18.6 & 6.1 & 3.9 & 3.2 & 3.8 & Elgasim \&Alkanhal (1992) \\
Beef & 7.7 & 7.1 & 10.8 & 16.5 & 6.2 & 4.5 & 4.2 & 4.1 & \\
Lamb & 6.7 & 6.9 & 10.3 & 17.9 & 5.5 & 3.8 & 2.9 & 3.5 & \\
Goat & 4.7 & 7.1 & 10.8 & 15.6 & 5.2 & 3.8 & 3.6 & 5.9 & \\
Camel & 6.5 & 6.9 & 9.7 & 17.0 & 6.2 & - & 4.3 & 3.3 & Al-Shabib \& Abu Tarboush (2004) \\
\hline
\end{tabular}

${ }^{1}$ Amino acid: Ala - Alanine, Arg- Arginine, Asp - Aspartic acid, Glu - Glutamic acid, Gly - Glycine, Pro - Prolene, Ser - Serine, Tyr - Ttyrosine

Table 4. Fatty acids composition (\%) of the Infraspinatus (IS), Triceps brachii (TB), Longissimus thoraces (LT), Semitendinosus (ST), Semimembranosus (SM), and Biceps femoris (BF) muscles of the dromedary camel (Kadim et al., 2013).

\begin{tabular}{|c|c|c|c|c|c|c|c|}
\hline & \multicolumn{7}{|c|}{ Muscle } \\
\hline & IS & TB & LT & ST & SM & $\mathrm{BF}$ & SEM $^{1}$ \\
\hline \multicolumn{8}{|l|}{ Saturated fatty acid } \\
\hline $12: 0$ & $1.71^{\mathrm{c}}$ & 1.42 & $1.13^{\mathrm{a}}$ & 1.66 & 1.53 & 1.44 & 0.186 \\
\hline 13:0 & 1.22 & 1.13 & 1.24 & 1.24 & 1.24 & 1.21 & 0.066 \\
\hline 14:0 & 7.62 & 7.78 & 7.16 & 7.24 & 7.48 & 7.83 & 0.544 \\
\hline $15: 0$ & 2.32 & 2.14 & 2.39 & 2.40 & 2.35 & 2.12 & 0.095 \\
\hline $16: 0$ & 27.64 & 27.26 & 26.92 & 25.09 & 26.45 & 26.16 & 2.378 \\
\hline $17: 0$ & 2.38 & 2.17 & 2.46 & 2.21 & 2.38 & 2.15 & 2.088 \\
\hline 18:0 & 8.79 & 8.90 & 9.82 & 8.71 & 8.37 & 8.02 & 2.277 \\
\hline 20:0 & 0.08 & 0.03 & 0.09 & 0.02 & 0.04 & 0.03 & 0.022 \\
\hline 21:0 & 0.03 & 0.00 & 0.03 & 0.01 & 0.01 & 0.00 & 0.007 \\
\hline 22:0 & 0.02 & 0.01 & 0.02 & 0.01 & 0.00 & 0.02 & 0.004 \\
\hline \multicolumn{8}{|l|}{ Mono-unsaturated fatty acids } \\
\hline $14: 1$ & 1.63 & 1.62 & 1.35 & 1.73 & 1.63 & 1.62 & 0.112 \\
\hline $15: 1$ & 1.04 & 1.03 & 1.01 & 1.01 & 1.03 & 1.02 & 0.051 \\
\hline $16: 1$ & 8.88 & 8.56 & 8.25 & 8.79 & 8.66 & 8.57 & 2.233 \\
\hline $17: 1$ & 0.16 & 0.14 & 0.14 & 0.15 & 0.11 & 0.11 & 0.039 \\
\hline C18:1n9 & 25.04 & 26.26 & 26.21 & 26.42 & 26.80 & 26.88 & 2.182 \\
\hline \multicolumn{8}{|l|}{ Poly-unsaturated fatty acids } \\
\hline $\mathrm{C} 18: 2 \mathrm{n} 6$ & 7.14 & 7.83 & 7.11 & 7.79 & 7.98 & 7.94 & 0.207 \\
\hline C18:3n3 & 0.64 & 0.43 & 0.59 & 0.62 & 0.54 & 0.54 & 0.122 \\
\hline C20:2 & 0.52 & 0.34 & 0.62 & 0.64 & 0.43 & 0.42 & 0.016 \\
\hline C20:3n6 & 0.33 & 0.23 & 0.34 & 0.43 & 0.42 & 0.41 & 0.009 \\
\hline C20:4n6 & 2.81 & 2.72 & 2.84 & 2.83 & 2.55 & 3.51 & 0.033 \\
\hline Total saturated FA (SFA) & 51.81 & 50.84 & 51.26 & 48.59 & 49.85 & 48.98 & 8.942 \\
\hline Total unsaturated FA (USFA) & 48.19 & 49.16 & 48.74 & 50.41 & 50.15 & 51.02 & 2.311 \\
\hline Total Mono- unsaturated FA (MUSFA) & 36.75 & 37.61 & 37.24 & 38.10 & 38.23 & 38.20 & 2.174 \\
\hline Total Poly - unsaturated FA (PUSFA) & 11.44 & 11.55 & 11.50 & 12.31 & 11.92 & 12.8 & 0.217 \\
\hline SFA: USFA & 1.08 & 1.03 & 1.05 & 0.96 & 0.99 & 0.98 & 3.869 \\
\hline SFA: MUSFA & 1.41 & 1.35 & 1.38 & 1.28 & 1.30 & 1.28 & 4.113 \\
\hline SFA: PUSFA & 4.54 & 4.40 & 4.46 & 3.95 & 4.18 & 3.82 & 4.120 \\
\hline
\end{tabular}

${ }^{1}$ SEM: standard error for the mean. Means on the same row with different superscripts are significantly different $(\mathrm{P}<0.05)$. 
Table 5. Fatty acid composition of the fat in camel meat.

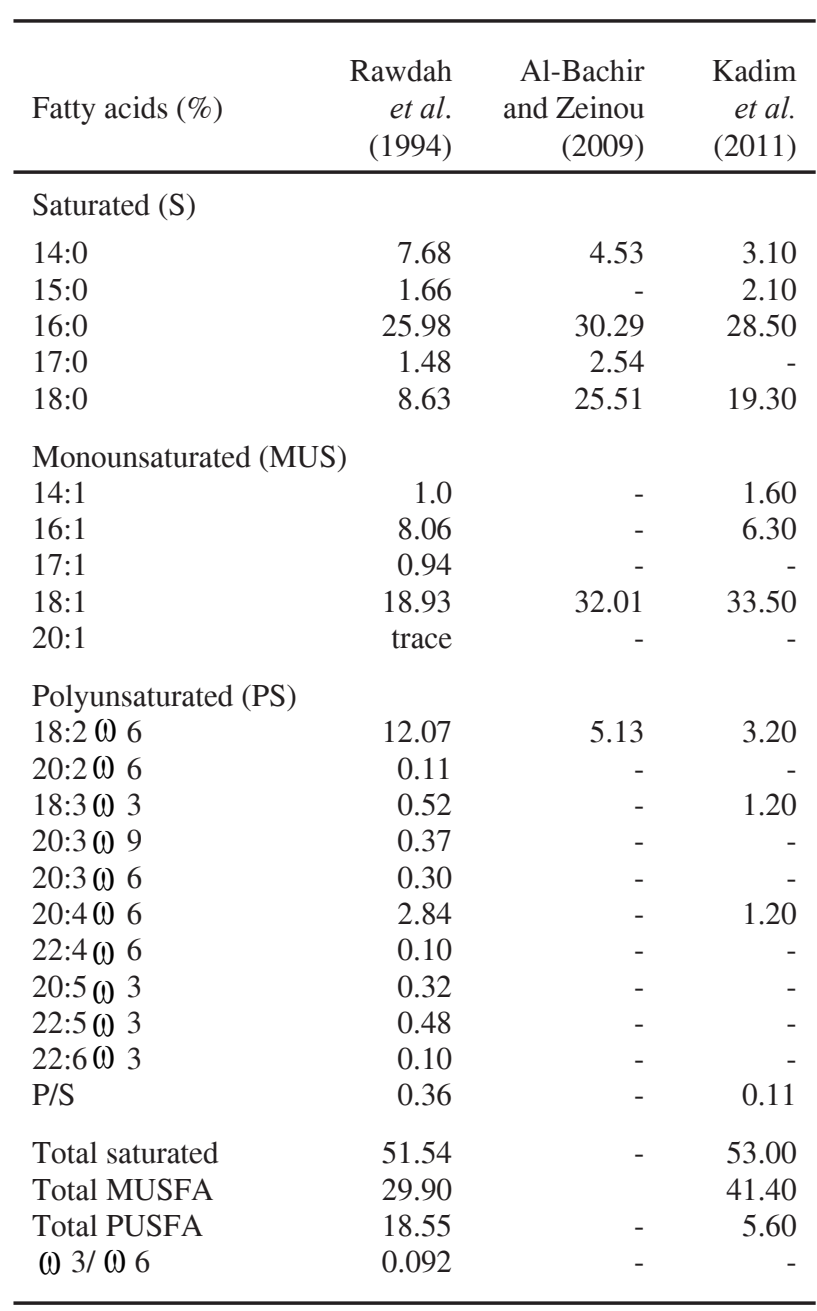

thoraces, Semitendinosus, Semimembranosus, and Biceps femoris muscles of the dromedary was studied by Kadim et al. (2013) (Table 5). The fatty acid composition of the six muscles was generally similar with the exception of palmitic and oleic fatty acids. The Semitendinosus muscle had lower palmitic acid than Infraspintus, Triceps brachii, Longissimus thoraces and Semimembranosus muscles. The Infraspintus muscle contained lower oleic acids than other muscles. Of the six muscles studied, palmitic acid is the most abundant saturated fatty acid in camel intramuscular fat, followed by stearic acid, and myristic acid. The main monounsaturated fatty acids in the six muscles were oleic acid followed by palmitoleic acid. The main polyunsaturated fatty acids in the muscles were linoleic acid and archidonic acid. The percentage of polyunsaturated fatty acids in camel meat (18.6\%) was within the range reported for beef $(8.8 \%)$ and buffalo (28.6\%) and deer (31.4\%) (Sinclair et al., 1982). The ratio of linoleic and linolenic acids in camel meat is about 10.9 which is much higher than that of the meat of cattle, sheep or goat (2.0, 2.4 and 2.8, respectively) (Sinclairb et al., 1982).
The camel hump is commonly used as cooking oil in camel producing countries. On a fresh weight basis, the camel hump is composed of about $64.2-84.8 \%$ fat, with a very high content of saturated fatty acids of about 63.0\% (Rawdah, et al., 1994; Kadim et al., 2002). Researchers, therefore, focused on the composition of the hump (Mirgani, 1977; Emmanuel and Nahapetian, 1980; Abu-Tarboush and Dawood, 1993; Kadim et al., 2002). Palmitic acid, stearic acid and oleic acid are the most abundant fatty acids in the hump. The composition of the hump fatty acids is affected by the animal age. The highest percentage of unsaturated fatty acids and lowest percentage of saturated fatty acids were in animals of less than one year whereas an opposite trend was in animals in the 1-3 years old age group (Kadim et al., 2002).

\section{Mineral Composition}

Minerals are generally classified as essential elements that are required for growth and health or toxic elements, which pose health risk to animals and humans. Both the deficiency and excess intake of essential elements as well as exceeding the safe limits of toxic elements can be detrimental to human health. Table 6 gives essential mineral contents of various cuts of camel meat by various authors.

Calcium content (mg/100g fresh weight) was reported to be in the range of 4.9- 11.48 (Table 6). The level of variation reported by Kadim et al. (2006; 2011), indicates that physiological factors play a major role in determining the calcium contents in camel meat. Small variations in calcium content are found among different meat cuts (Table 6). The calcium content between different meat cuts range from 10 to 27\% (Dawood and Alkanhal, 1995; Rashed, 2002) Cobalt and chromium contents were in the range of 0.003-0.004 and 0.008- 0.03 (mg/100g fresh weight) (Kadim et al., 2006). Copper contents in camel meat ranged between 0.04 to $0.12 \mathrm{mg} / 100 \mathrm{~g}$ fresh weight (Table $6)$. The foreleg contains a higher copper content compared with other meat cuts (Rashed, 2002). The iron content in camel meat (1.16-3.39 mg/100 g fresh meat) varied among different meat cuts (Table 6) which is most probably due to the different physiological requirements of myoglobin of different muscles. As with other red meat species, meat cuts containing oxidative muscles (e.g. leg and neck) have a higher iron content than glycolytic muscles. Potassium is the major element in camel meat (193.4-379.1 mg/100g fresh weight) and magnesium content in camel meat ranges between 10.41- $21.03 \mathrm{mg} / 100 \mathrm{~g}$ fresh weight (Kadim et al., 2009). Meat cuts from the limbs have higher potassium and magnesium content compared with the loins and ribs (Table 6). Meat from Saudi Arabian camels contained similar manganese content $(0.01 \mathrm{mg} / 100 \mathrm{~g}$ fresh weight $)$ across four different meat cuts (El-Faer et al., 1991; Elgasim and Alkanhal, 1992). However, meat from camels in Egypt appears to have higher manganese content (mg/ $100 \mathrm{~g}$ dry matter) and the concentration varied among different meat cuts (Rashed, 2002). The sodium content in 
Table 6. Mineral concentrations in camel meat $(\mathrm{mg} / 100 \mathrm{~g}$ fresh weight.

\begin{tabular}{|c|c|c|c|c|c|c|c|c|c|c|c|c|c|c|}
\hline \multirow[b]{2}{*}{ Factor } & \multicolumn{13}{|c|}{ Mineral $^{1}$} & \\
\hline & $\mathrm{Ca}$ & Co & $\mathrm{Cr}$ & $\mathrm{Cu}$ & $\mathrm{Fe}$ & K & $\mathrm{Mg}$ & $\mathrm{Mn}$ & Mo & $\mathrm{Na}$ & $\mathrm{P}$ & S & $\mathrm{Zn}$ & \\
\hline Rump & - & 0.004 & - & 0.12 & 2.5 & - & - & - & 0.04 & - & - & - & - & $\begin{array}{l}\text { Badiei et } \\
\text { al. (2006) }\end{array}$ \\
\hline Intercostal & 8.5 & 0.29 & 0.42 & 0.13 & 51.0 & 515 & 29.5 & 0.19 & - & 300.5 & - & - & 74.0 & \multirow{6}{*}{$\begin{array}{l}\text { Rashed } \\
(2002)\end{array}$} \\
\hline Scapula & 10.0 & 0.35 & 0.32 & 0.21 & 54.5 & 670 & 51.0 & 0.22 & - & 225.0 & - & - & 58.0 & \\
\hline Sirloin & 10.2 & 0.27 & 0.41 & 0.16 & 44.0 & 446 & 28.0 & 0.16 & - & 188.5 & - & - & 66.0 & \\
\hline Flank & 8.4 & 0.32 & 0.33 & 0.12 & 49.0 & 811 & 49.5 & 0.19 & - & 223.0 & - & - & 69.5 & \\
\hline Front knuckle & 8.4 & 0.26 & 0.42 & 0.25 & 44.5 & 630 & 37.0 & 0.17 & - & 299.5 & - & - & 73.5 & \\
\hline Front limb & 9.8 & 0.19 & 0.37 & 0.26 & 50.5 & 548 & 42.5 & 0.19 & - & 312.5 & - & - & 85.5 & \\
\hline Chuck & 11.5 & - & - & - & 3.2 & 249 & 17.4 & - & - & 73.5 & - & - & 3.7 & \multirow{3}{*}{$\begin{array}{c}\text { Dawood } \\
\text { \&Alkanhal } \\
\text { (1995) }\end{array}$} \\
\hline Ribeye & 8.1 & - & - & - & 2.9 & 231 & 16.3 & - & - & 67.1 & - & - & 3.7 & \\
\hline leg & 10.3 & - & - & - & 3.4 & 251 & 17.1 & - & - & 69.7 & - & - & 3.9 & \\
\hline Leg+loin & 4.9 & - & - & 0.04 & 1.9 & 228 & 17.7 & 0.01 & - & 47.9 & - & - & 3.2 & $\begin{array}{l}\text { Elgasim } \\
\text { \&Alkanhal } \\
(1992)^{2}\end{array}$ \\
\hline Shoulder & 5.1 & - & 0.01 & 0.07 & 1.2 & 357 & 20.6 & 0.01 & - & 69.1 & 196 & 56.1 & 3.5 & \multirow{4}{*}{$\begin{array}{l}\text { El-Faer et } \\
\text { al. (1991) }\end{array}$} \\
\hline Thigh & 5.4 & - & 0.01 & 0.09 & 1.4 & 361 & 21.0 & 0.01 & - & 70.4 & 199 & 55.0 & 3.1 & \\
\hline Ribs & 4.7 & - & 0.01 & 0.07 & 1.2 & 324 & 18.5 & 0.01 & - & 84.1 & 181 & 58.0 & 3.9 & \\
\hline Neck & 5.6 & - & 0.03 & 0.09 & 1.4 & 338 & 18.5 & 0.01 & - & 87.3 & 181 & 64.4 & 4.8 & \\
\hline \multicolumn{15}{|c|}{ Effect of specie } \\
\hline Camel & 5.9 & 0.003 & 0.008 & - & - & 193 & 12.9 & - & 0.08 & 45.3 & 105 & - & - & \multirow{2}{*}{$\begin{array}{l}\text { Kadim et al. } \\
\quad(2009 \mathrm{a})\end{array}$} \\
\hline Beef & 6.2 & 0.003 & 0.009 & - & - & 416 & 20.5 & - & 0.006 & 51.0 & 162 & - & - & \\
\hline Camel & 4.9 & - & - & 0.04 & 1.94 & 228 & 17.7 & 0.01 & - & 47.9 & - & - & 3.2 & Elgasim \& \\
\hline Beef & 6.97 & - & - & 0.06 & 2.66 & 277 & 24.8 & 0.02 & - & 31.2 & - & - & 4.1 & $\begin{array}{c}\text { Alkanhal } \\
\text { (1992) }\end{array}$ \\
\hline
\end{tabular}

${ }^{1}$ Mineral: Ca - Calcium, Co - cobalt, Cr - Chromium, Cu - Copper, Fe - Iron, K- Potassium, Mg - magnesium, Mn - Manganese, Mo - Molybdenum, $\mathrm{Na}$ - Sodium, P - Phosphorus, S - Sulfate, Zn -Zinc

camel meat was in the range of 40.2-87.3 mg/100g (Table $7)$. The loin cuts had the lowest sodium content among the different meat cuts (Elgasim and Alkanhal, 1992; Rashed, 2002; Kadim et al., 2006). Phosphorus is the second most abundant element in camel meat (105.6-199.0 mg/100g fresh weight) and the leg and shoulder cuts have a slightly higher phosphorus content than ribs and neck cuts (ElFaer et al., 1991). The sulfur content was in the range of 54.99-136.57 mg/100g fresh weight. The sulfur content in four meat cuts varied by $17 \%$ only (El-Faer et al., 1991). Red meat is an important source of zinc. Camel meat contains about 3.07 to $4.80 \mathrm{mg} / 100 \mathrm{~g}$ fresh weight (Table 6). The variation between different cuts was $7.6 \%$ (Dawood and Alkanhal, 1995) but a higher percentage of variation (47-56\%) has been reported in other studies (ElFaer et al., 1991; Rashed, 2002).

The mineral concentrations of Infraspinatus, Triceps brachii, Longissimus thoraces, Semitendinosus,
Semimembranosus, and Biceps femoris muscles of the dromedary (Kadim et al., 2013) and bactrian camels (Raiymbek et al., 2012) are presented in Table 7. The phosphorus magnesium, sodium, potassium and iron contents of camel muscle samples varied between muscles. The Triceps brachii muscles and had the highest mean value of phosphorus, calcium, magnesium and potassium (Table 7). The Semitendinosus muscle in the dromedary and bactrian camels had more magnesium than Infraspinatus, Triceps brachii, Longissimus thoracis, and Biceps femoris muscles. The Semitendinosus and Semimembranosus muscles had more iron than other muscles in the dromedary. The Longissimus thoracis muscle had a lower and the Triceps brachii higher $(\mathrm{P}<0.05)$ potassium than other muscles (Table 7). For trace elements (zinc, iron, lead, selenium, copper), there was small variation between the muscles of dromedary and bactrian camels (Table 7). 
Table 7. Macro and micro-element levels (mg/100g) in Infraspinatus (IS), Triceps brachii (TB), Longissimus thoraces (LT), Semitendinosus (ST), Semimembranosus (SM), and Biceps femoris (BF) muscles of the dromedary (Kadim et al., 2013) and bactrian camels (Raiymbek et al., 2012b).

\begin{tabular}{|c|c|c|c|c|c|c|c|c|c|c|c|c|}
\hline & \multicolumn{6}{|c|}{ Dromedary } & \multicolumn{6}{|c|}{ Bactrian } \\
\hline & \multicolumn{6}{|c|}{ Muscle } & \multicolumn{6}{|c|}{ Muscle } \\
\hline & IS & TB & LT & ST & SM & $\mathrm{BF}$ & IS & TB & LT & ST & SM & $\mathrm{BF}$ \\
\hline Phosphorus & 6.49 & 7.76 & 5.23 & 6.39 & 7.96 & 6.79 & 3.32 & 3.72 & 2.29 & 3.97 & 3.66 & 3.74 \\
\hline Calcium & 0.07 & 0.08 & 0.05 & 0.07 & 0.08 & 0.07 & 0.05 & 0.05 & 0.05 & 0.05 & 0.05 & 0.05 \\
\hline Magnesium & 1.73 & 2.21 & 1.37 & 3.39 & 2.17 & 1.84 & 2.48 & 3.03 & 2.51 & 3.5 & 3.27 & 3.45 \\
\hline Sodium & 6.33 & 5.98 & 5.18 & 7.38 & 5.78 & 6.93 & 5.01 & 4.57 & 3.59 & 5.78 & 4.93 & 5.16 \\
\hline Potassium & 81.7 & 103 & 25.2 & 71.3 & 80.9 & 85.6 & 74.4 & 80.5 & 36.9 & 80.0 & 77.7 & 73.5 \\
\hline Zinc & 0.01 & 0.01 & 0.01 & 0.01 & 0.01 & 0.01 & 0.02 & 0.02 & 0.01 & 0.02 & 0.02 & 0.02 \\
\hline Iron & 0.02 & 0.06 & 0.03 & 2.42 & 2.52 & 0.05 & 0.06 & 0.08 & 0.05 & 0.08 & 0.12 & 0.08 \\
\hline Lead & 0.001 & 0.01 & 0.01 & 0.01 & 0.03 & 0.002 & 0.03 & 0.03 & 0.03 & 0.03 & 0.03 & 0.02 \\
\hline Selenium & 0.003 & 0.003 & 0.004 & 0.004 & 0.003 & 0.003 & & & & & & \\
\hline Copper & 0.002 & 0.001 & 0.001 & 0.05 & 0.07 & 0.004 & 0.002 & 0.002 & 0.004 & 0.002 & 0.002 & 0.001 \\
\hline
\end{tabular}

${ }^{1}$ SEM: standard error for the mean. Means on the same row with different superscripts are significantly different $(\mathrm{P}<0.05)$.

The concentrations of silver, gold and nickel in five camel meats have been reported at 0.06-0.12, 0.10-0.21 and $0.05-0.38 \mathrm{mg} / 100 \mathrm{~g}$ dry matter, respectively (Rashed, 2002). The concentration of the three minerals varied among different muscles by 100, 110 and $750 \%$ (Table 8 ). The concentrations of nickel, beryllium and vanadium increased in the dromedary camel Longissimus thoracis with increasing animal age (Kadim et al., 2006). The level of lead in camel Longissimus thoracis was 2.5 times the concentration in beef Longissimus thoracis (Kadim et al., 2009). Studies on the levels of trace and heavy elements in camel blood concluded that camels could be less efficient than other ruminants in detoxifying these elements in its body (Al-Qarawi and Ali, 2003).The monitoring of toxic material levels in camel products should pay particular attention to toxic compounds in the offal because this is consumed by low income people as a source of animal protein (Faye et al., 2008).

Nutrition, management, breed, sex and age of animals play an important role in determining the level of various elements in the meat and the camel blood (Faye et al., 2008). For instance, the calcium content in the camel

Table 8. Toxic/non-essential elements concentrations (mg/100g)_of fresh weight.

\begin{tabular}{|c|c|c|c|c|c|c|c|c|}
\hline \multirow[b]{2}{*}{ Factor } & \multicolumn{7}{|c|}{ Mineral $^{1}$} & \\
\hline & $\mathrm{Ag}$ & $\mathrm{Al}$ & $\mathrm{Au}$ & $\mathrm{Cd}$ & $\mathrm{Ni}$ & $\mathrm{Pb}$ & $\mathrm{Sr}$ & \\
\hline \multicolumn{9}{|c|}{ Effect of meat cut } \\
\hline Intercostal & 0.07 & - & 0.11 & - & 0.24 & - & - & \multirow{6}{*}{ Rashed (2002) } \\
\hline Scapula & 0.06 & - & 0.10 & - & 0.38 & - & - & \\
\hline Sirloin & 0.11 & - & 0.19 & - & 0.05 & - & - & \\
\hline Flank & 0.09 & - & 0.12 & - & 0.13 & - & - & \\
\hline Front knuckle & 0.12 & - & 0.17 & - & 0.19 & - & - & \\
\hline Front limb & 0.11 & - & 0.21 & - & 0.21 & - & - & \\
\hline Shoulder & - & 0.51 & - & - & - & - & 0.02 & \multirow{4}{*}{ El-Faer et al. (1991) } \\
\hline Thigh & - & 0.15 & - & - & - & - & 0.03 & \\
\hline Ribs & - & 0.12 & - & - & - & - & 0.02 & \\
\hline Neck & - & 0.58 & - & - & - & - & 0.03 & \\
\hline \multicolumn{9}{|l|}{ Effect of specie } \\
\hline Camel & - & - & - & 0.003 & 0.025 & 0.015 & - & \multirow{2}{*}{ Kadim et al. (2009b) } \\
\hline Beef & - & - & - & 0.003 & 0.044 & 0.006 & - & \\
\hline
\end{tabular}

${ }^{1}$ Mineral: Ag - Silver, Al - Aluminum, Au - gold, CD - cadmium - Ni - nickel, Pb - Lead, Sr - Strontium 
Table 9. Effect of age on some meat quality characteristics of the dromedary camel Longissimus thoracis muscle.

\begin{tabular}{|c|c|c|c|c|c|}
\hline & \multicolumn{3}{|c|}{$\begin{array}{l}\text { Kadim et al. } \\
\quad \text { (2006) }\end{array}$} & \multicolumn{2}{|c|}{$\begin{array}{l}\text { Kadim et al. } \\
\quad(2009 \mathrm{~b})\end{array}$} \\
\hline & \multicolumn{3}{|c|}{$\begin{array}{l}\text { Age group } \\
(\mathrm{yr})\end{array}$} & \multicolumn{2}{|c|}{$\begin{array}{l}\text { Age group } \\
(\mathrm{yr})\end{array}$} \\
\hline & $1-3$ & $3-5$ & $5-8$ & $1-2$ & $8-10$ \\
\hline Ultimate $\mathrm{pH}$ & 5.91 & 5.84 & 5.71 & 5.68 & 5.65 \\
\hline $\begin{array}{l}\text { WB- Shear force } \\
\text { value (Newton) }\end{array}$ & 68.4 & 79.5 & 131.9 & 66.1 & 87.3 \\
\hline $\begin{array}{l}\text { Sarcomere length } \\
(\mu \mathrm{m})\end{array}$ & 1.85 & 1.24 & 1.06 & 1.66 & 1.60 \\
\hline $\begin{array}{l}\text { Myofibrillar } \\
\text { fragmentation } \\
\text { Index }(\%)\end{array}$ & 80.99 & 73.3 & 60.4 & 72.2 & 67.3 \\
\hline $\begin{array}{l}\text { Expressed juice } \\
\left(\mathrm{cm}^{2} / \mathrm{g}\right)\end{array}$ & 29.6 & 27.36 & 21.26 & 38.1 & 37.4 \\
\hline Cooking loss (\%) & 26.06 & 23.72 & 22.42 & 23.4 & 22.0 \\
\hline \multicolumn{6}{|l|}{ Colour parameters } \\
\hline$L^{*}$ (lightness & 37.74 & 34.03 & 31.69 & 39.1 & 38.1 \\
\hline$a^{*}$ (redness & 13.37 & 13.82 & 16.18 & 16.5 & 15.6 \\
\hline$b^{*}$ (yellowness) & 6.09 & 6.78 & 7.26 & 5.58 & 6.29 \\
\hline
\end{tabular}

meat reported from the same laboratory (Kadim et al., 2006; 2011) or across different laboratories (Dawood and Alkanhal, 1995; Kadim et al., 2006) supports this contention. It is worth mentioning that the biological variation of elements even within the same herd that has a similar farming background is very high (Kadim et al., 2006).

\section{Meat Quality Characteristics}

Camel meat is often regarded as inferior to other meats. This might be attributed to the strong reluctance of camel owners to sell their young stock, and they usually slaughter older camels at the end of their productive life. Most camel meat trade is of meat from old camels with a low quality, which has a direct bearing on the extent of demand for meat outside the camel herding societies. However, numerous studies have reported that meat quality characteristics from young dromedary camels are comparable to those of beef (Leupold, 1968; Fischer, 1975; Knoess, 1977; Mukasa-Mugerwa, 1981; Kadim et al., 2006, 2009; Shariatmadari and Kadivar, 2006). Nevertheless, camel meat had a significantly lower level of sarcoplasmic proteins as a proportion of total proteins than beef (Babiker and Tibin, 1986).

Camels 2-4 years-old and beef 2-3 years-old had similar meat quality characteristics of the Longissimus thoracis muscle (Kadim and Mahgoub, 2008). The camel Longissimus thoracis, Semitendinosus and Triceps brachii muscles lose more water during cooking than beef ( $48 \%$ vs. $37 \%$ ) while no tenderness differences were observed between the two species (Kamoun, 1995a,b). In contrast,
Babiker and Tibin (1986) reported that camel meat has less cooking losses and higher water holding capacity than beef meat. The effect of age on meat quality is discussed in order to optimize the best age for slaughtering camel for high quality meat. Table 9 depicts the effect of camel age on meat quality parameters and shows that meat becomes less tender and of inferior quality with increasing animal age (Kadim et al., 2006). However, Kamoun (1995a,b) noted that age is not a predominant factor in meat quality, in the case of dromedarius fed the same diet and slaughtered between one and four years of age. Kadim et al. (2006) suggested that the male camels should be slaughtered between one to three years of age. This is in agreement with the conclusion of Dina and Klintegerg (1977). At this age the animals were not yet fully grown, averaging about $60-70 \%$ of full live weight, and therefore, their meat is tender.

Meat quality parameters of Longissimus thoracis and Biceps femoris muscles inf our Indian camel breeds was compared by Suliman et al. (2011), and the results indicated little variation between the four breeds (Table 10). The shear force values in Longissimus thoracis muscles ranged from $6.45 \mathrm{~kg}$ in Magahem to $14.32 \mathrm{~kg}$ in Shoal, while in Biceps fermoris muscles the ranges were between $19.44 \mathrm{~kg}$ for Wodoh to 23.3 for Shoal. On the other hand, various breeds exhibited a similar myofibrillar fragmentation index, ultimate $\mathrm{pH}$ and sarcomere length for both Longissimus thoracis and Biceps femoris (Table 10). Muscles of the loin region were tenderer than those from the leg.

The eating quality of six muscles of the dromedary camel was studied by Kamoun (1995b) who concluded that the Vastuslateralis muscles had the highest weight and volume losses (51.1 and $47.8 \%$, respectively) whereas Psoas major muscles had the lowest (44.6 and $41.1 \%$, respectively) (Table 11). The Triceps brachii and Vastuslateralis muscles contained more soluble collagen than Semitendinosus, Psoas major, Longissimus thoracis and Semimembranosus muscles, possibly indicating a less thermal stable bond between collagen molecules and weaker connective tissue structures of those muscles (Kamoun, 1995b). Although all six muscles studied by Kamoun (1995b) were ranked acceptable for tenderness, the Longissimus thoracis muscle was tenderer and had less detectable connective tissue than the other muscles. The Longissimus thoracis muscle had the highest juiciness score and the Semitendinosus and Vastuslateralis muscles were less juicy than Psoas major, Semimembranosus and Triceps brachii muscles.

\section{Ultimate Muscle pH}

The ultimate $\mathrm{pH}$ of muscles is a consequence of lactic acid accumulation via glycolysis that affects meat quality characteristics (Simek et al., 2003). According to Laack et al. (2001), 40-50\% of variation in ultimate $\mathrm{pH}$ is determined by glycogen concentration. It needs $0.81 \mathrm{~g} / 100 \mathrm{~g}$ of glycogen to lower the $\mathrm{pH}$ of one $\mathrm{kg}$ of muscle from 7.2 
Table 10. Effect of Camel breed on some meat quality characteristics of the dromedary camel Longissimus thoracis and Biceps femoris muscles (Suliman, et al., 2011).

\begin{tabular}{|c|c|c|c|c|c|c|c|c|}
\hline & \multicolumn{8}{|c|}{ Breed } \\
\hline & \multirow{2}{*}{\multicolumn{2}{|c|}{$\frac{\text { Magahem }}{\text { Muscle }^{1}}$}} & \multirow{2}{*}{\multicolumn{2}{|c|}{$\frac{\text { Wodoh }}{\text { Muscle }^{1}}$}} & \multirow{2}{*}{\multicolumn{2}{|c|}{$\frac{\text { Shoal }}{\text { Muscle }^{1}}$}} & \multirow{2}{*}{\multicolumn{2}{|c|}{$\begin{array}{c}\text { Sofor } \\
\text { Muscle }^{1}\end{array}$}} \\
\hline & & & & & & & & \\
\hline & $\mathrm{LT}$ & $\mathrm{BF}$ & $\mathrm{LT}$ & $\mathrm{BF}$ & $\mathrm{LT}$ & $\mathrm{BF}$ & $\mathrm{LT}$ & $\mathrm{BF}$ \\
\hline Ultimate $\mathrm{pH}$ & 5.76 & 5.90 & 5.87 & 5.90 & 5.91 & 5.82 & 6.07 & 6.03 \\
\hline WB- Shear force value (kg) & 6.45 & 23.32 & 13.73 & 19.44 & 14.32 & 23.25 & 10.40 & 22.77 \\
\hline Sarcomere length $(\mu \mathrm{m})$ & 1.69 & 1.68 & 1.68 & 1.66 & 1.64 & 1.69 & 1.65 & 1.67 \\
\hline Myofibrillar fragmentation index (\%) & 71.6 & 62.4 & 66.2 & 60.9 & 65.4 & 63.0 & 67.0 & 61.2 \\
\hline Cooking loss $(\%)$ & 23.7 & 28.3 & 21.9 & 26.0 & 22.9 & 31.2 & 22.4 & 28.7 \\
\hline \multicolumn{9}{|l|}{ Colour parameters } \\
\hline$L^{*}$ (lightness) & 31.6 & 30.0 & 33.4 & 28.1 & 31.6 & 31.2 & 31.2 & 29.7 \\
\hline$a^{*}$ (redness) & 11.8 & 13.3 & 13.0 & 13.6 & 12.8 & 13.4 & 15.0 & 13.1 \\
\hline$b^{*}$ (yellowness) & 4.03 & 4.07 & 4.74 & 3.91 & 4.43 & 4.26 & 4.85 & 3.91 \\
\hline
\end{tabular}

${ }^{1}$ Muscle: LT - Longissimus thoraces, BF - Biceps femoris.

to 5.5 (Warris, 1990). The ultimate $\mathrm{pH}$ of camel muscles is the result of a combination of many factors including pre-slaughter handling, postmortem treatment, glycogen storage and muscle physiology. Low muscle glycogen stores at slaughter prevents the development of a desirable pH postmortem (Ashmore et al., 1973). A high ultimate

Table 11. Eating quality attributes of the six major muscles (Kamoun, 1995b).

\begin{tabular}{lcccccc}
\hline & \multicolumn{6}{c}{ Muscle $^{1}$} \\
\cline { 2 - 7 } Parameter & PM & LT & SM & ST & VL & TB \\
\hline $\begin{array}{l}\text { Myoglobin } \\
(\mathrm{mg} / \mathrm{g})\end{array}$ & 3.9 & 4.1 & 5.8 & 3.4 & 4.1 & 5.1 \\
$\begin{array}{l}\text { Collagen (mg/g) } \\
\text { Sensory }\end{array}$ & 3.3 & 4.1 & 5.0 & 7.5 & 6.6 & 5.6 \\
$\begin{array}{l}\text { tenderness } \\
\begin{array}{l}\text { Collagen soluble } \\
(\%)\end{array}\end{array}$ & 29 & 6.6 & 3.7 & 3.6 & 1.9 & 3.9 \\
$\begin{array}{l}\text { Sensory } \\
\text { juiciness }\end{array}$ & 6.2 & 6.8 & 5.2 & 3.8 & 4.1 & 5.8 \\
$\begin{array}{l}\text { Cooking weight } \\
\text { loss (\%) }\end{array}$ & 45 & 45 & 49 & 48 & 51 & 51 \\
$\begin{array}{l}\text { Cooking volume } \\
\text { loss (\%) }\end{array}$ & 41 & 42 & 46 & 44 & 48 & 45 \\
\hline
\end{tabular}

${ }^{1}$ Muscle: PM - Psoas major, LT - Longissimus thoracis, SM - Semimembranosus, ST - Semitendinosus, VL - Vastus lateralis, TB - Triceps brachii.
$\mathrm{pH}$ in camel muscles is a consequence of low muscle glycogen as a result of pre-slaughter stress, including, poor nutrition, rough handling and long transportation. The ultimate $\mathrm{pH}$ has an effect on several meat properties like colour, tenderness, water-holding capacity, flavor, and drip loss all of which influences consumer acceptance of camel meat. Glycogen degradation speed differs between "red" and "white" muscles. Red muscles have many red fibres, which contract slowly, have an oxidative metabolism and a low concentration of glycogen. White muscles contract rapidly and have a high concentration of glycogen, normally with a glucolytic metabolism and an active degradation to lactic acid (Lawrie, 2006).

The ultimate $\mathrm{pH}$ of dromedary camel meat ranges between 5.5 and 6.6 (Babiker and Yousif, 1990; Kadim et al., 2006, 2009a,b, 2010, 2013). Generally, young camels tend to produce meat with a higher $\mathrm{pH}$ than older camels due to lower levels of glycogen. In this respect, Kadim et al. (2006) found that camels younger than three years had a $\mathrm{pH}$ value (5.91) which was higher than camels older than six years (5.71). The ultimate $\mathrm{pH}$ of Longissimus thoracis muscles varied between 5.53 and 5.75 and between 5.68 and 5.80 for electrically stimulated and non-stimulated camel carcasses, respectively (Kadim et al., 2009a). The breed of camels did not differ in terms of ultimate $\mathrm{pH}$ in Longissimus thoracis and Biceps femoris muscles (Suliman et al., 2011).

\section{Tenderness (Shear Force Value)}

Tenderness is the most important organoleptic characteristic and is the predominant quality determinant of meat compared to flavor and colour (Koohmaraie, 
1988). Muscle characteristics, glycogen content, collagen content, solubility, and the activities of proteases and their inhibitors are the most important physiological parameters that determine meat tenderness (Hocquette et al., 2005). Major variation in meat tenderness is related to the variability of muscle characteristics (Renand et al., 2001). The Longissimus thoracis muscle had more soluble collagen than the Semitendinosus and Triceps brachii muscles (Kamoun et al., 1995b). The Triceps brachii muscle had the highest shear force values, maximum connective tissue strength and lowest collagen solubility compared to Longissimus thoracis, Semitendinosus, Semimembranosus, Psoas major and Vastuslateralis in camels, indicating that it is the toughest muscle in this group (Babiker and Youssif, 1990) The Psoas major and Longissimus thoracis muscles were the most tender and had less detectable connective tissue than other muscles. In another study, Kadim et al. (2013) found that Infraspinatus, Triceps brachii and Longissimus thoracis camel muscles had lower shear force values than semitendinosus, semimembranosus and biceps femoris muscles, which might be due to less connective tissue (Table 12).

Raiymbek et al. (2012) reported a similar observation for bactrian camel muscles (Table 12). The tenderization process starts after slaughter and it varies among individual carcasses and depends on the postmortem activity of the calpainproteolytic enzymes that include calpastatin (Parr et al., 1999). The most marked difference in meat quality characteristics between camel meat and other livestock is largely believed to be tenderness (Mukasa-Mugerwa, 1981). Camels are usually slaughtered at the end of their productive life (more than10 years) which is classified as of low quality compared with meant from other animals. Average shear force value of camel meat at 5-8 years was $48 \%$ and $40 \%$ higher than those of 1-3 and 3-5 year olds, respectively (Kadim et al., 2006). A number of studies have also shown that shear values of meat increase with increasing camel age (Dawood, 1995; Kadim et al., 2006). Differences due to age may be related to changes in muscle structure and composition as an animal matures, particularly in the nature and quantity of connective tissue (Asghar and Pearson, 1980), Significant differences $(\mathrm{P}<0.05)$ were found between the different ages $(8,16$ and 26 months of age) and cuts (chuck, ribeye and leg) for shear force values of male Nahdi camels (Dawood, 1995).

\section{Aging}

Historically, meat has been aged to improve its quality characteristics because meat is often unacceptably tough immediately following rigor onset. Ageing is the process that causes an improvement in tenderness, flavour, colour and texture over time and involves specific degradation of structural proteins (Hwang et al., 2003; Jaturasitha et al., 2004). The time required for ageing varies with the type, size, species, and age of the animal. Moderate temperature

Table 12. Meat quality characteristics of six muscles of the dromedary and bactrian camel carcasses.

\begin{tabular}{|c|c|c|c|c|c|c|c|c|c|c|c|c|}
\hline \multirow[b]{5}{*}{ Age (yr) } & \multicolumn{12}{|c|}{ References } \\
\hline & \multicolumn{6}{|c|}{ Kadim et al. (2013) } & \multicolumn{6}{|c|}{ Raiymbek et al. (2012) } \\
\hline & \multicolumn{6}{|c|}{ Muscle $^{1}$} & \multicolumn{6}{|c|}{ Muscle $^{1}$} \\
\hline & IS & $\mathrm{TB}$ & $\mathrm{LT}$ & ST & SM & $\mathrm{BF}$ & IS & TB & $\mathrm{LT}$ & ST & SM & $\mathrm{BF}$ \\
\hline & \multicolumn{6}{|c|}{$1.5-2$} & \multicolumn{6}{|c|}{$2-3$} \\
\hline Ultimate $\mathrm{pH}$ & 5.64 & 5.73 & 5.61 & 5.67 & 5.83 & 5.74 & 5.73 & 5.69 & 5.63 & 5.68 & 5.60 & 5.68 \\
\hline WB-Shear Force & 34.8 & 42.1 & 41.8 & 36.8 & 42.4 & 40.2 & 10.8 & 8.9 & 6.0 & 10.0 & 9.8 & 8.6 \\
\hline Sarcomere length $(\mu \mathrm{m})$ & 31.6 & 29.2 & 33.5 & 28.5 & 30.6 & 29.5 & 1.45 & 1.54 & 1.70 & 1.47 & 1.53 & 1.52 \\
\hline $\begin{array}{l}\text { Myofibrillar fragmentation } \\
\text { index }(\%)\end{array}$ & 6.3 & 6.7 & 6.5 & 9.0 & 12.9 & 10.3 & 76.8 & 76.9 & 73.9 & 77.7 & 76.7 & 78.4 \\
\hline Water-holding capacity & 1.7 & 1.7 & 1.7 & 1.5 & 1.4 & 1.5 & 38.2 & 37.9 & 37.1 & 40.4 & 41.3 & 38.8 \\
\hline Cooking loss (\%) & 31.6 & 29.2 & 33.5 & 28.5 & 30.6 & 29.5 & 32.7 & 32.6 & 25.1 & 34.3 & 33.9 & 32.1 \\
\hline \multicolumn{13}{|l|}{ Colour } \\
\hline$L^{*}$ & 41.7 & 40.2 & 43.5 & 40.5 & 40.6 & 40.6 & 32.4 & 30.8 & 33.4 & 30.2 & 30.8 & 30.1 \\
\hline$a^{*}$ & 12.7 & 12.6 & 14.0 & 10.5 & 13.6 & 13.3 & 13.2 & 13.1 & 13.8 & 12.8 & 13.8 & 13.5 \\
\hline$b^{*}$ & 2.6 & 3.7 & 4.1 & 2.2 & 2.9 & 3.8 & 3.8 & 3.4 & 3.9 & 3.2 & 3.5 & 3.6 \\
\hline
\end{tabular}

${ }^{1}$ Muscle: IS - Infraspintus, TB - Triceps brachii, LT - Longissimus thoracis, ST - Semitendinosus, SM - Semimembranosus, BF - Biceps femoris. 
Table 13. Effects of age and ageing on meat quality attributes of Longissimus thoracis of dromedary camel (Kadim et al., 2009a).

\begin{tabular}{|c|c|c|c|c|c|c|c|c|}
\hline & \multicolumn{8}{|c|}{ Age (year) } \\
\hline & \multicolumn{2}{|c|}{$1-3$} & \multicolumn{2}{|c|}{$4-6$} & \multicolumn{2}{|c|}{$7-9$} & \multicolumn{2}{|c|}{$10-12$} \\
\hline & $\begin{array}{l}\text { Ageing } \\
\text { 7-day }\end{array}$ & $\begin{array}{l}\text { Ageing } \\
\text { 2-day }\end{array}$ & $\begin{array}{r}\text { Ageing } \\
\text { 7-day }\end{array}$ & $\begin{array}{r}\text { Ageing } \\
\text { 2-day }\end{array}$ & $\begin{array}{r}\text { Ageing } \\
\text { 7-day }\end{array}$ & $\begin{array}{r}\text { Ageing } \\
\text { 2-day }\end{array}$ & $\begin{array}{r}\text { Ageing } \\
\text { 7-day }\end{array}$ & $\begin{array}{r}\text { Ageing } \\
\text { 2-day }\end{array}$ \\
\hline Ultimate $\mathrm{pH}$ & 5.86 & 5.85 & 5.79 & 5.78 & 5.71 & 5.71 & 5.60 & 5.61 \\
\hline Expressed juice (cm2/g) & 38.6 & 37.2 & 37.2 & 36.6 & 30.8 & 30.3 & 21.3 & 21.1 \\
\hline Cooking loss $(\%)$ & 25.7 & 25.0 & 23.9 & 22.7 & 21.3 & 19.8 & 18.9 & 17.8 \\
\hline WB-shear force (kg) & 7.28 & 8.10 & 8.41 & 8.97 & 9.14 & 9.76 & 11.29 & 12.79 \\
\hline Sarcomere length $(\mu \mathrm{m})$ & 1.73 & 1.47 & 1.65 & 1.67 & 1.48 & 1.47 & 1.39 & 1.37 \\
\hline Myofibrillar fragmentation index & 77.9 & 73.5 & 71.6 & 69.8 & 66.9 & 64.5 & 62.7 & 60.2 \\
\hline Lightness (L*) & 40.5 & 39.80 & 38.71 & 36.86 & 35.31 & 33.72 & 30.15 & 28.47 \\
\hline Redness $\left(\mathrm{a}^{*}\right)$ & 15.6 & 15.7 & 16.9 & 16.1 & 18.2 & 19.0 & 19.9 & 19.5 \\
\hline Yellowness (b*) & 5.40 & 5.51 & 6.04 & 6.03 & 7.03 & 7.05 & 7.93 & 7.98 \\
\hline
\end{tabular}

storage may accelerate the ageing process by keeping carcasses at temperatures of $15^{\circ} \mathrm{C}$ or greater (Petrovic et al., 1993). The ageing processes originate within the myofibers and are responsible for degradation of cellular constituents. This resembles the method adopted by Kadim et al. (2009a), where camel Longissimus thoracis muscles were stored at a temperature of $2-3^{\circ} \mathrm{C}$ for seven days. Ageing at $2-3^{\circ} \mathrm{C}$ for 7 -days improved camel meat quality characteristics (Table 13). This implies that ageing may be one of the postmortem treatments which increase camel meat tenderness that might be adopted in the camel meat industry. According to Lagerstedt et al., 2008), increasing ageing time from four to seven days may cause more cooking losses in beef meat. However, Kadim et al. (2009a) found no differences in cooking loss with ageing of camel Longissimus thoracis muscles from two to seven days. The level of improvement in tenderness within a certain ageing time varies among different meat cuts, ages of the animal and species due to differences in the level of endogenous enzymes, contraction status and connective tissue content (George-Evins et al., 2004). In general, ageing can improve quality characteristics of meats that have relatively small amounts of connective tissue and that have not cold-shortened (Wheeler et al., 1999).

\section{Myofibrillarfragmentation Index}

The myofibrillar fragmentation index is a useful indicator of the extent of myofibrillar protein degradation of postslaughter camel meat (Kadim et al., 2006, 2009a,b, 2011, 2013; Raiymbek et al., 2012). The differences in rates of fragmentation of myofibrillar proteins may account for differences in the rate of postmortem tenderization of meat (Nagaraj et al., 2005). The structural changes occurring in muscle tissue after slaughter are generally believed to be caused by alterations in and interactions of myofibrillar proteins in the tissue (Nagaraj et al., 2006). Claeys et al. (1994) reported that at a higher $\mathrm{pH}$, proteins preferentially solublized were titin, filamin, nebulinand myosin heavy chain. Except for myosin, all are preferentially degraded by calpains, which has an optimum effect atpH values near neutrality. Similarly, Silva et al. (1999) verified that the myofibrillar fragmentation index in meat was significantly higher at ultimate $\mathrm{pH} 6.5$ than at 5.7. There is a correlation between the myofibrillar fragmentation index and the tenderness of meat (Veisethet al., 2001). The myofibrillar fragmentation index of camels above 6 years was lower than those of 1-3 years of age (Kadim et al., 2008, 2009a). The same authors established a strong relationship between physical disruptions of the myofibrils and the tenderness of camel meat.

\section{Water Holding Capacity (Expressed Juice)}

Water retention in meat is primarily caused by immobilization of water within the myofibrillar system. Applying pressure can cause a shift of water from the intercellar to the extracellular space and then onto the meat surface as a result of structural alterations at the level of the sarcomeres or of the myofilaments structure. Water retention affects the retention of minerals, vitamins and volume of water (Beriain et al., 2000) and is influenced by muscle $\mathrm{pH}$ because of the electrostatic effects of meat proteins (Hamm, 1975). The dromedary and bactrian camel meats contain higher expressed juice than other camelidae such as llama and alpaca, possibly because of the lower fat content (Cristofaneli et al., 2004). The amount of water loss was likely due to the ultimate $\mathrm{pH}$ of the muscle, composition of muscle and denaturation of proteins by the ionic strength of the extracellular fluid and oxidation of lipids which decreases the solubility of proteins (Dyer and Dingle, 1967). Kadim et al. (2006) reported that meat 
from camels slaughtered at one to three years had higher water-holding capacity values than those slaughtered at five to eight years of age, probably due to variations in fat content and the binding ability of meat proteins (Table 9). The water-holding capacity decreases as fat levels increase due to an increase in the ratio of moisture to fat (Miller et al., 1968). Dawood (1995) reported that young camel meat (eight months of age) had significantly higher waterholding capacities than meat from 26 month-old camels.

The volume of the dromedary camel meat was reduced by $44.3 \%$ and weight by $48.2 \%$ after being boiled in water for $40 \mathrm{~min}$ (Kamoun, 1995b). The Longissimus thoracis and Biceps femoris muscles from mature camels had 37.9 and $37.1 \%$ cooking loss which was higher than the $33.2 \%$ cooking loss in Semitendinosus muscle, which coincided with its high water-holding capacity (Babiker and Yousif, 1990). A higher cooking loss was observed in the Longissimus thoraces muscle (33.5\%) when compared to the Infraspinatus (31.6\%), Triceps brachii (29.2\%), Semitendinosus (28.5\%), Semimembranosus (30.6\%) Biceps femoris $(29.5 \%)$ with no significant differences between the last five muscles (Kadim et al., 2013). In the bactrian camel (Table 12), variation in expressed juice between Infraspinatus, Triceps brachii, Longissimus thoracis, Semitendinosus, Semimembranosus, and Biceps femoris muscles ranged from $37.10 \mathrm{~cm}^{2} / \mathrm{g}$ (Longissimus thoraces) to $41.27 \mathrm{~cm}^{2} / \mathrm{g}$ (Semimembranosus) $\mathrm{cm}^{2} / \mathrm{g}$ (Raiymbek et al., 2012a). The variation between muscles might be due to location, activity, proportion of muscle fiber types, $\mathrm{pH}$, intramuscular fat and the ratio of water to protein of individual muscles. However, Suliman et al. (2011) found that Biceps femoris muscles had a higher cooking loss than Longissimus thoraces muscles in four different camel breeds. According to Shehata (2005), young camels (10-12 months old) had a higher cooking loss than old animals. Longissimus thoracis from two to three year old camels had significantly lower cooking loss $(24.3 \%)$ than the values mentioned above (Kadim et al., 2009a,b). The cooking loss of camel longissimus thoracis was not different from that in cattle Longissimus thoracis of the same age. Cooking loss is important because of its potential to change the level of nutrients in the meat once it is cooked. For example, while it generally regarded that the protein content of camel meat is similar to other red meats (Elgasim and Alkanhal, 1992; Gheisari et al., 2009), the higher cooking loss in camel meat (33-38\%), compared to beef (24.6\%), will generate a more nutritionally dense cooked meat (Kadim et al., 2009).

\section{$\operatorname{Colour}\left(L^{*}, a^{*}, b^{*}\right)$}

Meat colour is one of the most important sensory characteristics according to which consumers make judgments on meat quality. The degree of meat pigmentation is directly related to the chemical structure of myoglobin content. Myoglobin concentration within a given muscle will differ according to the species or age and is dependent on muscle fibre type proportions, muscle
$\mathrm{pH}$, age, intramuscular fat, and muscle texture (Gardner et al., 1999; Lawrie, 2006). There was a negative linear relationship between colour values and $\mathrm{pH}$ in Longissimus thoracis muscles (Menzies and Hopkines, 1996). Postmortem protein degradation is directly related to the ultimate $\mathrm{pH}$, which increases light scattering properties of meat and thereby increases $L^{*}$ value (Offer, 1991). Low ultimate $\mathrm{pH}$ meat samples might lead to more protein degradation resulting in higher colour values than the high ultimate $\mathrm{pH}$ meat samples. Abril et al. (2001) reported that reflectance spectrum value for meat samples was higher for an ultimate $\mathrm{pH}$ above 6. Postmortem glycolysis decreases muscle $\mathrm{pH}$ making muscle surfaces brighter and superficially wet. If the ultimate meat $\mathrm{pH}$ is high, the physical state of the proteins will be above their isoelectric point, and the proteins will associate with more water in the muscle and therefore, fibers will be more tightly packed (Abril et al., 2001). Babiker and Yousif (1990) reported that dromedary camel Longissimus dorsi muscles had higher lightness $\left(L^{*}\right)$, redness $\left(a^{*}\right)$ and yellowness $\left(b^{*}\right)$ values than Semitendinosus and Triceps brachii muscles. Suliman et al. (2011) found that the colour of the Biceps femoris muscle was not affected by breed of camels. A high redness $\left(a^{*}\right)$ colour component in the camel Longissimus thoracis muscle was associated with a lower lightness $\left(L^{*}\right)$, which might be due to an increase in myoglobin content. Camel muscle lightness $L^{*}$ values indicated that the Longissimus thoraces muscle (43.5) had the lightest $(\mathrm{P}<0.05)$ lean colour, which was possibly due to high fat content (Kadim et al., 2013). The Semitendinosus muscle had the darkest coloured lean compared to Infraspinatus, Longissimus thoraces, Triceps brachii, Semimembranosus, and Biceps femoris camel muscles. The Longissimus thoraces, semimembranosus and biceps femoris dromedary camel muscles had higher redness $\left(a^{*}\right)$ values than the Semitendinosus muscle, while $\mathrm{a}^{*}$ value for Infraspinatus and Triceps brachii muscles were in between. CIE $a^{*}$ values were similar among Longissimus thoraces, Semimembranosus and Biceps femoris muscles (Kadim et al., 2013). In camels, the highest average yellowness $\left(b^{*}\right)$ value was recorded in the Longissimus thoraces muscle with comparable values to the Triceps brachii and Biceps femoris muscles.

In bactrian camel, the Longissimus thoraces muscle had higher lightness $\left(L^{*}\right)$ values and Infraspinatus han Triceps brachii, Semitendinosus, Semimembranosus and Biceps femoris muscles (Raiymbek et al., 2012a). The age of the camels has a significant effect on their meat colour (Kadim et al., 2006). Meat colour from 6-8 and 10-12 year old dromedary camels was darker (lower $L^{*}$ ), redder (higher $a^{*}$ ) and yellower (high $b^{*}$ ) than 1-3 year old camels because of higher concentrations of myoglobin (Kadim et al., 2006).

\section{Health Aspects of Camel Meat}

Meat is a valuable source of food rich in many essential amino acids, minerals, vitamins and bioactive compounds 
such as carnosine, anserine, glutathione and essential fatty acids such as Omega 3 fatty acids (Williams, 2007; Schonfeldt and Gibson, 2008). Apart from the nutritional value of meat, it provides several eating attributes and fulfilling experiences that normally are not achieved by other protein sources. Beef, lamb, pork, poultry and fish are considered the major sources of animal protein worldwide. However, in Africa, the Middle East and some Asian countries, especially in arid and semi-arid regions, camel meat is regarded as a main source of animal protein that equals and in some cases surpasses other meats in commercial importance.

Several epidemiological studies linked health problems such as obesity and high saturated fat and cholesterol intake to increased consumption of animal products (Biesalski, 2005; Chao et al., 2005). This has led to a concern that total dietary fat intake should be restricted by consuming smaller portions less frequently (Schonfeldt and Gibson, 2008) or replacing red meat consumption with white meat. The low cholesterol and fat contents in camel meat could potentially be considered as a better alternative to the higher fat and cholesterol contents of mutton and beef.

\section{Camel Meat as Medicine}

Meat in general is considered a functional food for cures of many ailments and for improved performance in many cultures around the world (Migdal and Živkovic, 2007). Camel meat and offals such as liver are believed to have medicinal properties and are eaten raw (Bin Saeed et al., 2005). Kadim et al. (2008) stated that Somalis and Indians particularly believe in the health benefits of consuming camel meat. Among many African and Asian countries, camel meat has traditionally been used to cure the following ailments: (1) seasonal fever, sciatica and shoulder pain, as well as for removing freckles (by placing hot camel meat slices on the freckled area); (2) camel meat soup was used to cure corneal opacity and to strengthen eyesight; (3) camel fat was used to ease hemorrhoidal pains and the hump fat was used to remove tapeworm; and (4) dried camel lungs used to be prescribed as a cure for asthma, especially if taken with honey. Kurtu (2004) reported that the majority of camel meat consumers believe it is a healthier option during the dry season in which cattle are infected with various zoonotic diseases. This belief probably originated from the historical use of animals' organs, including meat, in folklore and traditional medicine. Lev (2006) cited the use of camel meat in remedial formulation by Al-Tabari, AlKindi and Al-Qazwini which indicate the roots of some of the current beliefs.

The camel is distinguished from other animals by the fact that the percentage of its intramuscular fat declines as the animal gets older. This quality, only found in camels, makes their meat less fatty, so its consumption is healthy and recommended for weight loss. And this quality also reduces the risk of cardiovascular disease and atherosclerosis since it lowers the percentage of cholesterol in the blood. Camel meat has other medical qualities, too, such as protecting against cancerous tumors, as claimed by some researchers, because it contains unsaturated fatty acids like linoleic acid which interact with other unsaturated fatty acids taken from vegetable oils to protect against cancer. Camel meat can also be used as a cure for exhaustion and fatigue because it contains energy needed by body cells. Such energy comprises sugar not fat, since, a camel's fat is concentrated in its hump whereas other animals store it in their muscles. In addition, camel meat contains glycogen, a carbohydrate which is easily absorbed and metabolized in the body, and which is converted to glucose which in turn activates nerve as well as other cells.

\section{Conclusion}

The nutritional value of dromedary and bactrian camel meat is similar to other red meats. However, meat from young camels can be considered as a healthy option due to its low fat and cholesterol contents. The quality characteristics of camel meat are similar to beef meat quality when they are slaughtered at similar ages. According to the composition and quality parameters of camel meat, it can be successfully marketed alongside that from cattle, deer, sheep and goat. Pre- and post mortem factors should be carefully considered to improve meat quality characteristics.

\section{References}

Abril, M., M.M. Campo, A. Onenc, C. Sanudo, P. Alberti, and A.I. Negueruela 2001. Beef colour evaluation as a function of ultimate $\mathrm{pH}$. Meat Science 58:69-78.

Abu-Tarboush, H.M. and A.A. Dawood. 1993. Cholesterol and fat contents of animal adipose tissues. Food Chemistry 46:89-93.

Al-Bachir, M. and R. Zeinou. 2009. Effect of gamma irradiation on microbial load and quality characteristics of minced camel meat. Meat Science 82:119-124.

Al-Qarawi, A.A. and B.H. Ali. 2003. Variations in the normal activity of esterases in plasma and liver of camels, cattle, sheep and goats. Journal of Veterinary Medicine 50:201-203.

Al-Shabib, N.A. and H.M. Abu-Tarboush. 2004. Nutritional value and some functional properties of protein in ostrich and camel meat. Arab Journal of Food Nutrition 5:6-20.

Asghar, A. and A.M. Pearson. 1980. Influence of ante- and postmortem treatments upon muscle composition and meat quality. Advances in Food Research 26:53-213.

Ashmore, C.R., F. Carroll, J. Doerr, G. Tompkins, H. Stokes, and W. Parker. 1973. Experimental prevention of dark-cutting meat. Journal of Animal Science 35: 33-36.

Babiker, S.A. and I.M. Tibin, 1986. Comparative study of camel meat and beef. Camel Research Unit, University of Khartoum, Sudan. 
Babiker, S.A. and O.K. Yousif. 1990. Chemical composition and quality of camel meat. Meat Science 27:283-287.

Badiei, K., K. Mostaghni, M. Pourjafar, and A. Parchami. 2006. Serum and tissue trace elements in Iranian camels (Camelus dromedarius). Comparative Clinical Pathology 15:58-61.

Beriain, M.J., A. Purroy, T. Treacher. and P. Bas. 2000. Effect of Animal and Nutritional Factors and Nutrition on Lamb Meat Quality. In: Sheep and Goat Nutrition: Intake, Digestion, Quality of Products and Rangeland, I. Ledin and P. Morand-Fehr (Editors),75-86. Zaragoza:CIHEAM (Cahiers Options Mediterraneennes; n. 52).

Biesalski, H. 2005. Meat as a component of a healthy diet - are there any risks or benefits if meat is avoided in the diet? Meat Science 70:509-524.

Bin Saeed, A.A., N.A. Al-Hamdan, and R.E. Fontaine. 2005. Plague from eating raw camel liver. Emerging Infectious Diseases 11:1456- 1457.

Chao, A., M. Thun, C. Connell, M. McCullough, E. Jacobs, and W. Flanders. 2005. Meat consumption and risk of colorectal cancer. The Journal of the American Medical Association 293:172-182.

Chizzolini, R., E. Zanardi, V. Dorigoni, and S. Ghidini. 1999. Calorific value and cholesterol content of normal and low-fat meat and meat products. Trends in Food Science and Technology 10:119-128.

Claeys, E., L. Uytterhaegen, D. Demeyer, and S. De Smet. 1994. Beef myofibrillar protein salt solubility in relation to tenderness and proteolysis. Proceedings of the $40^{\text {th }}$ International Congress of Meat Science and Technology (S-IVB. 09), The Hague, The Netherlands.

Cristofaneli, S., M. Antonini, D.Torres, P. Polidori, and C. Renieri. 2004. Meat and carcass quality from Peruvian llama (Lama glama) and alpaca (Lama pacos). Meat Science 66:589-593.

Dawood, A. 1995. Physical and sensory characteristics of Najdi camel meat. Meat Science 39:59-69.

Dawood, A. and M.A. Alkanhal. 1995. Nutrient composition of Najdi camel meat. Meat Science 39: 71-78.

Dina, D. and R. Klintegerg. 1977. Proposal for a rural development training project and study concerned with camel utilization in arid lands in Ethiopia. Addis Abab (Mimeographed). Quoted by Shalah, 1979 and Wilson, 1984.

Dorman, A.E. 1986. Aspects of the husbandry and management of the Genus Camelus. In: The Camel in Health and Disease, A. Higgins (Editor), 3-20. BalliereTindall, London.

Dyer, W.J. and J.R. Dingle. 1967. Fish as Food. G. Borgstrom (Editor), Academic Press, New York.

E1-Faer, M.Z., T.N. Rawdah, K.M. Attar, and M.V. Dawson. 1991. Mineral and proximate composition of the meat of the one-humped camel (Camelus dromedaries). Food Chemistry 42:139-143.

Elgasim, E.A. and M.A. Alkanhal, 1992. Proximate composition, amino acids and inorganic mineral content of Arabian camel meat: comparative study. Food Chemistry 45:1-4.

Elgasim, E.A. and G.A. Elhag. 1992. Carcass characteristics of the Arabian camel. Camel Newsletter 9:20-24.

Elgasim, E.A., G.A. El-Hag, and F.A. Elnawawi. 1987. Quality attributes of camel meat. $2^{\text {nd }}$ Congress Report, the Scientific Council, King Faisal University, Alhash, KSA.

Emmanuel, B. and A. Nahapetian. 1980. Fatty acid composition of depot fats and rumen wall of the camel (Camelus dromedaries). Comparative Biochemistry and Physiology 67B:701-704.

Faye, B., R. Seboussi, and M. Askar. 2008. Trace elements and heavy metals in Arabian camel. In: Impact of Pollution on Animal Products, B. Faye and Y. Sinyavskiy (Editors), 1-16. Springer Science + Business Media B.V.

Fischer, H. 1975. Schaf, zeigen-wasserbuffel und dromedarhaltung. In: KonKurreuz fat Runderhaltung. Beitrage III veterinaragung, Ouagadougoa. p1-16.

Gardner, G.E., L. Kennedy, J.T.B. Milton, and D. Pethic. 1999. Glycogen metabolism and ultimate $\mathrm{pH}$ of muscle in Merino, first-cross, and second-cross wether lambs as affected by stress before slaughter. Australian Journal of Agricultural Research 50:175181.

George-Evins, C.D., J.A. Unruh, A.T. Waylan, and J.L. Marsden. 2004. Influence of quality classification, aging period, blade tenderization, and endpoint cooking temperature on cooking characteristics and tenderness of beef Gluteus medius steak. Journal of Animal Science 82:1863-1867.

Gheisari, H.R. and H. Motamedi. 2010. Chloride salt type/ionic strength and refrigeration effects on antioxidant enzymes and lipid oxidation in cattle, camel and chicken meat. Meat Science 86:377-383.

Gheisari, H.R. 2011. Correlation between acid, TBA, peroxide and iodine values, catalase and glutathione peroxidase activities of chicken, cattle and camel meat during refrigerated storage. Veterinary World 4:153157.

Gheisari, H.R., M. Aminlari, and S.S. Shekarforoush. 2009. A comparative study of the biochemical and functional properties of camel and cattle meat during frozen storage. Veterinarski Arhiv 79:51-68.

Hamm, R. 1975. Water-holding capacity of meat. In: Meat, D.A.J. Cole and R.A. Lawrie (Editors), 321328. London: Butterworths.

Hocquette, J.F., I.C. Malek, R. Jailler, and B. Picard. 2005. Recent advances in research on bovine muscle and meat sensory quality. II. Influence of 
rearing factors on muscle characteristics. Cahiers Agricultures 14:365-372.

Hwang, I.H., C.E. Devine, and D.L. Hopkins. 2003. The biochemical and physical effects of electrical stimulation on beef and sheep meat tenderness. Meat Mensink, R.P. and M.B. Katan. 1989. Effects of a diet enrich with monounsaturated or polyunsaturated fatty acids on levels of low density and high density lipoproteins cholesterol in healthy women and men. The New England Journal of Medicine 231:436-441.

Jaturasitha, S., P. Thirawong, V. Leangwunta, and M.Kreuzer. 2004. Reducing toughness of beef from BosIndicus draught steers by injection of calcium chloride: effect of concentration and time postmortem. Meat Science 68:61-69.

Kadim, I.T., O. Mahgoub, R.S. Al-Maqbaly, K. Annamalai, and D.S. Al-Ajmi. 2002. Effects of age on fatty acid composition of the hump and abdomen depot fats of the Arabian camel (Camelus dromedarius). Meat Science 62:245-251.

Kadim, I.T. and O. Mahgoub. 2006. Meat quality and composition of Longissimus thoracis from Arabian camel (Camelus dromedaries) and Omani beef: a comparative study. Proceedings of the $1^{\text {st }}$ Conference of International Society of Camelids Research and Development (ISOCARD), p118. Al-Ain, United Arab Emirates.

Kadim, I.T., O. Mahgoub, W. Al-Marzooqi, S. AlZadgali, K. Annamalai, and M.H. Mansour. 2006. Effects of age on composition and quality of muscle Longissimus thoracis of the Omani Arabian Camel (Camelus dromedarius). Meat Science 73:619-625.

Kadim, I.T. and O. Mahgoub. 2008. Effect of age on quality and composition of one-humped camel Longissimus thoracis muscle. International Journal of Postharvest Technology and Innovation 1:327-336.

Kadim, I.T., O. Mahgoub, and R.W. Purchas. 2008. A review of the growth, and of the carcass and meat quality characteristics of the one-humped camel (Camelus dromedaries) Meat Science 73:619-625.

Kadim, I.T., O. Mahgoub, W. Al-Marzooqi, and S.K. Khalaf. 2009a. Effect of low voltage electrical

stimulation and splitting carcass on histochemical and meat quality characteristics of the one-humped camel (Camelus dromedaries) Longissimus thoracis muscle. Journal of Camelid Science 2:30-40.

Kadim, I.T., O. Mahgoub, W. Al-Marzooqi, S.K. Khalaf, M.H. Mansour, S.S.H. Al-Sinani and I.S.

Al-Amri. 2009b. Effects of electrical stimulation on histochemical muscle fiber staining, quality, and composition of camel and cattle Longissimus thoracis muscles. Journal of Food Science 74: S44- S52.

Kadim, I.T., M.R. Al-Ani, R.S. Al-Maqbaly, M.H. Mansour, O. Mahgoub, and E.H. Johnson. 2011. Proximate, amino acid, fatty acid and mineral composition of raw and cooked camel (Camelus dromedarius) meat. British Food Journal 113:482493.

Kadim ,I.T., A. Al-Karousi, O. Mahgoub, W. Al-Marzooqi, R. Al-Maqbaly, S.K. Khalaf, and G. Raiymbek. 2013. Physical, chemical, quality and histochemical characteristics of infraspinatus, triceps brachii, longissimus thoraces, biceps femoris, semitendinosus, and semimembranosus of Dromedary camel (Camelus dromedaries) muscles. Meat Science 93:564-571.

Kamoun, M. 1995a. Dromedary meat: production, qualitative aspects and capability for transformation. Option Mediterraneennes Serie B, Etudes Recherches 13:105-130.

Kamoun, M. 1995b. Evolution de la qualite de la carcasse et de la viande des dromadaires En function de la conduit zootechnique des animaux. Rapport final relative a la bourse de recherché FIS no. 1372-2.

Khanvilkar, A.V., M.D. Kulkarni, G.B. Yadav, S.R. Samant, V.J. Thorat, and M.G. Shisode. 2009. Desert friendly animal - the camel. Veterinary World 2:240241.

Khatami, K. 1970. Camel meat: a new promising approach to the solution of meat and protein in the arid and semiarid countries of the world. Ministry of Agriculture, Tehran.

Knoess, K.H. 1977. The camel as a meat and milk camel. World Animal Review 22:39-44.

Koohmaraie, M. 1988. The role of endogenous proteases in meat tenderness. Proceedings Recip. Meat Conference, 41:89-100.

Kurtu, M.Y. 2004. An assessment of the productivity for meat and carcass yield of camel (Camelus dromedarious) and the consumption of camel meat in the Eastern region of Ethiopia. Tropical Animal Health and Production 36:65-76.

Laack, R.V., R. Kauffman, and M. Greaser. 2001. Determinants of ultimate $\mathrm{pH}$ of meat. Proceedings of the $47^{\text {th }}$ International Congress of Meat Science and Technology 1: 22-26.

Lagerstedt, A., L. Enfalt, L. Johansson, and K. Lundstrom. 2008. Effect of freezing on sensory quality, shear force and water loss in beef M. Longissimus dorsi. Meat Science 80:457-461.

Lawrie, R.A. 2006. Lawrie's Meat Science (7th Ed.), Woodhead Publishing Limited, Cambridge, England.

Leupold, J. 1968. The camel an important domestic animal of the subtropics. Blue Book for the Veterinary Profession 15:1-6.

Lev, E. 2006. Healing with animals in the Levant from the 10th to the 18th century. Journal of Ethnopharmacology and Ethonmedicine, 2.doi:10.1186/1746-4269-2-11.

Mburu, D.N., G.W. Ochieng, S.G. Kuria, H. Jianlin, B. Kaufmann, J.E. Rege, and O. Hanotte. 2003. Genetic diversity and relationships of indigenous Kenyan camel (Camelus dromedarius) populations, implications for their classification. Animal Genetics 34:26-32. 
Menzies, D.J. and D.L. Hopkins, D.L. 1996. Relationship between color and ph in lamb loins. Proceedings Australian Society of Animal Production 21:353.

Miller, W.O., R.L. Staffle, and S.B. Zirkle. 1968. Factors, which influence the water-holding capacity of various types of meat. Food Technology 22:11390.

Mukasa-Mugerwa, E. 1981. The camel (Camelus dromedaries): a biographical review. ICLA Mongr. No. 5. Livest. Ctr. Africa, Addis Ababa, Ethiopia. p147.

Mensink, R.P. and M.B. Katan. 1989. Effects of a diet enrich with monounsaturated or polyunsaturated fatty acids on levels of low density and high density lipoproteins cholesterol in healthy women and men. The New England Journal of Medicine 231: 436-441.

Migdal, W. and B. Žirkovic. 2007. Meat - from functional food to disease of modern civilization. Biotechnology in Animal Husbandry 23:19-31.

Mirgani, T. 1977. Fatty acid composition of hump triglycerides of the camel Camelus dromedarius. Comparative Biochemistry and Physiology 588:211-213.

Murray, E.F. 1989. Medicine and Surgery of South American Camelids. Iowa State University Press, USA, 391pp.

Nagaraj, N.S., K.R. Anilakumar, and K. Santhanam. 2005. Postmortem changes in myofibrillar proteins of goat skeletal muscles. Journal of Food Biochemistry 29:152-170.

Nagaraj, N.S., K.R. Anilakumar, and K. Santhanam. 2006. Biochemical and physicochemical changes in goat meat during postmortem aging. Journal of Muscle Foods 17:198-213.

Offer, G. 1991. Modeling of the formation of pale, soft and exudative meat: effects of chilling regime and rate and extent of glycolysis. Meat Science 30:157-184.

Parr, T., P.L. Sensky, G.P. Scothern, R.G. Bardsley, P.J. Buttery, J.D. Wood, and C. Warkup. 1999. Relationship between skeletal muscle-specific calpain and tenderness of conditioned porcine Longissimus muscle. Journal of Animal Science 77:661-668.

Petrovic, L., R. Grujic, and M. Petrovic. 1993. Definition of the optimum freezing rate -2 . Investigation of the physico-chemical properties of beef M.. longissimus dorsi frozen at different freezing rates. Meat Science 33:319-331.

Renand, G., B. Picard, C. Touraille, P. Berge, and J. Lepetit. 2001. Relationships between muscle characteristics and meat quality traits of young Charolais bulls. Meat Science 59:49-60.

Raiymbek, G., B. Faye, G. Konuspayeva, and I.T. Kadim, 2012a. Meat quality characteristics of Infraspinatus, Triceps brachii, Longissimus thoraces, Biceps femoris, Semitendinosus, and Semimembranosus of bactrian (Camelus bactrianus) camel muscles. KazNu Bulletin Biology Series 54:27-31.

Raiymbek, G., Faye, B., Serikbayeva, A. Konuspayeva, G., and I.T. Kadim, I.T. 2012b. Chemical composition of Infraspinatus, Triceps brachii, Longissimus thoraces, Biceps femoris, Semitendinosus, and Semimembranosus of bactrian (Camelus bactrianus) camel muscles. Emirates Journal of Food and Agriculture 25:261-266.

Rashed, M.N. 2002. Trace elements in camel tissues from a semi-arid region. Environment 22:111-118.

Rawdah, T.N., M.Z. El-Faer, and S.A. Koreish. 1994. Fatty acid composition of the meat and fat of the onehumped camel (Camelus dromedarius). Meat Science 37:149-155.

Sallam, K.I. and A.M.A. Morshedy. 2008. Organochlorine pesticide residues in camel, cattle and sheep carcasses slaughtered in Sharkia Province, Egypt. Food Chemistry 108:154-164.

Schönfeldt, H. and N. Gibson. 2008. Changes in the nutrient quality of meat in an obesity context. Meat Science 80:20-27.

Shariatmadari, R. and M. Kadivar. 2006. Postmortem aging and freezing of camel meat (a comparative study). In: Proceedings $52^{\text {nd }}$ International Congress of Meat Science and Technology, Dublin, Ireland, p673674.

Shehata, M.F. 2005. Carcass traits and meat quality of one-humped camels fed different halophytic forages: 2-Physical, chemical, and sensory characteristics of camel meat. Mansoura University Journal of Agricultural Sciences 30:1943-1952.

Simek, J., L. Vorlova, L. Malota, I. Steinhauserova, and L. Steinhauser. 2003. Post-mortal changes of $\mathrm{pH}$ value and lactic acid content in the muscles of pigs and bulls. Journal of Animal Science 7:295-299.

Silva, J.A., L. Patarata, and C. Martins. 1999. Influence of ultimate $\mathrm{pH}$ on bovine meat tenderness during ageing. Meat Science 52 453-459.

Sinclair, A.J., W.J. Slattery, and K. O’Dea, K. 1982. The analysis of polyunsaturated fatty acids in meat by capillary gas-liquid chromatography. Journal of the Science of Food and Agriculture 33:771-776.

Suliman, G., A. Sami, A. Alowaimer, and M. Koohmaraie. 2011. Effect of breed on the quality attributes of camel meat. Indian Journal of Animal Science 81:407-411.

Tandon, S.N., U.K. Bissa, and N.D. Khanna. 1988. Camel meat: present status and future prospects. Annals of Arid Zone, 27:23-28.

Veiseth, E., D.D. Shackelford, T.L. Wheeler, and M. Koohmaraie. 2001. Technical note: composition of myofibril fragmentation index from fish and frozen pork and lamb Longissimus. Journal of Animal Science 79:904-906.

Warris, P. 1990. The handling of cattle pre-slaughter and its effects on carcass and meat quality. Applied Animal Behaviour Science 28:171-186.

Williams, P. 2007. Nutritional composition of red meat. Nutrition and Dietitian 64:S113-S119.

Wheeler, T.L., S.D. Shackelford, and M. Koohmaraie. 1999. Tenderness classification of beef; IV Effect of 
USDA quality grade on the palatability of "tender" beef Longissimus when cooked well done. Journal of Animal Science 77: 882-888.

Williams, P. 2007. Nutritional composition of red meat. Nutrition and Dietitian 64:S113-S119.

Wilson, R.T. 1998. Camel. In: The Tropical Agricultural Series, R. Costa (Editor), Centre for Tropical Veterinary Medicine, University of Edinburth.
Wood, J.D., M. Enser, A.V. Fisher, G.R. Nute, P.R. Sheard, R.I. Richardson, S.I. Hughes, and F.M. Whittington. 2008. Fat deposition, fatty acid composition and meat quality: a review. Meat Science 78:343-358.

Received: March 16, 2013

Accepted: June 18, 2013 